\title{
Compatible package-based agriculture systems: an urgent need for agro-ecological balance and climate change adaptation
}

\author{
Rishikesh Singh ${ }^{1, *}$, Tanu Kumari ${ }^{1}$, Pramit Verma ${ }^{1}$, Bhupinder Pal Singh ${ }^{2}$, Akhilesh Singh Raghubanshi ${ }^{1, *}$ \\ 1 Integrative Ecology Laboratory (IEL), Institute of Environment \& Sustainable Development (IESD), Banaras Hindu University, \\ Varanasi 221005, India \\ 2 NSW Department of Primary Industries, Elizabeth Macarthur Agricultural Institute, Menangle, NSW 2568, Australia
}

H I G H L I G H T S

- Resource-conservation practices are emerging for attaining sustainability in agriculture. - The research is now progressing towards combined application of emergent agronomic practices.

- Role of agro-climatic zones is imperative in developing compatible agronomic packages.

- Compatible agriculture packages may help in buffering the yield penalty occurred in single system.

- Compatible agriculture packages would be the need for attaining true sustainability in agriculture.

\section{ARTICLE INFO}

Article history:

Received November 1, 2020

Revised January 31, 2021

Accepted March 15, 2021

Keywords:

Agricultural policies

Bibliometric analysis

Biochar

Conservation agriculture

GHG emission

Organic farming

SRI

Sustainable agriculture
GRAPHICAL ABSTRACT

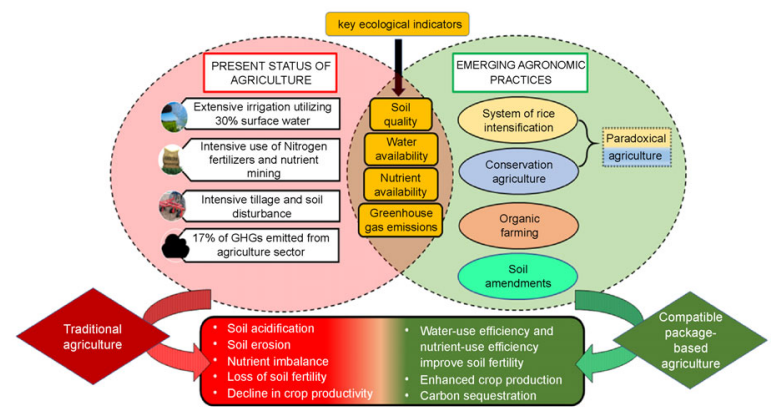

A B S T R A C T

Besides contributing majorly in the growth of a country, agriculture is one of the severely affected sectors at present. Several modifications and adaptations are being made in agricultural practices to cope-up with the declining soil fertility and changing climate scenarios across the world. However, the development and adoption of a single agricultural practice may not help in the holistic mitigation of the impacts of climate change and may result in economic vulnerability to farmers. Therefore, it is high time to develop and recommend a group of agricultural practices i.e., package-based agriculture system having some compatibility for one another in the long term. In this article, a viewpoint has been given on some emergent agronomic practices adopted in the tropical agroecosystems which have potential to be developed as compatible agricultural package in combination. Moreover, we also emphasized on exploring some key indicators/environmental factors to assess the compatibility of different agronomic practices. For identifying the research transition from single to combined agricultural practices, a bibliometric analysis was performed by using conservation agriculture (CA), the system of rice intensification (SRI), organic agriculture and soil (biochar) amendment as the major agronomic practices being used for improving agroecological services such as improving nutrient cycling, soil fertility and crop productivity as well as climate change mitigation. The results revealed that scientific communities are now paying attention to exploring the role of combined agricultural practices for agro-ecological balance and climate change adaptation. Moreover, the limitations of the adoption of agronomic packages under different agro-climatic zones have also been highlighted. The recommendations of the study would further help the environmental decision-makers to develop potential measures for climate change mitigation without compromising the agro-ecological balance.

(c) Higher Education Press 2021

\footnotetext{
* Corresponding authors

E-mail address: rishikesh.iesd@gmail.com (R. Singh); asr.iesd.bhu@gmail.com (A.S. Raghubanshi)
} 


\section{Introduction}

Agriculture provides a livelihood option for $>50 \%$ of people residing in rural areas, particularly in the developing nations (FAO, 2015). However, agriculture always remains at crossroads because of its close inter-linkages with the increasing global population, food security, diminishing natural resources and greenhouse gas (GHG) emission (FAO, 2011; Singh et al., 2019a) (Fig. 1). Earlier attempts to achieve the food security through green revolution included a package of genetically advanced high-yielding varieties, high rate of external nutrient inputs as synthetic fertilizers, intensive use of natural resources (water) and other agrochemicals (pesticides) (Saikia et al., 2012). The green revolution increased the crop yield, and thus, made the self-sufficiency in the required food production of a country (Singh et al., 2019a). Green revolution-based traditional crop management practices require high production cost and are resource-use inefficient (Jat et al., 2014). For example, massive consumption of agrochemicals holds the major reasons for the increase in food production during the first 20 years of the green revolution in India (Singh et al., 2019a). However, the resource-intensiveness of the agronomic packages in green revolution later resulted in the severe degradation of ecological health and its multi-functionality (Srivastava et al., 2016 a), leading to the stagnancy and/or even a decline of $25 \%-30 \%$ in cereal crop yield (Singh and Sidhu, 2006; Dhillon et al., 2010; Bose and Mondal, 2013). In spite of using recommended cultural practices, this trend was observed in several parts of the world such as the Philippines, India, Indonesia and Pakistan in the past 16 years (Pretty, 1995). In this respect, a close view on the status of agricultureenvironment interaction is the urgent need of the hour.

Although any agricultural system is developed with a major goal to enhance crop yield, for the long-term agricultural sustainability, environmental health should be the major concern. The traditional agricultural practices favor agrobased industries and large landholding farmers, whereas excessive agrochemical inputs increased the availability of phosphate, nitrate, ammonia, chloride and different heavy metals in the soil resulting in the declining soil quality and increased environmental pollution (Foley et al., 2011; Godfray and Garnett, 2014). Thus, the environmental impacts of agriculture need to be assessed in terms of water, nutrient (soil) and atmospheric (gaseous emission) components.

Water availability is one of the key factors determining the crop growth and performance, thus, the agricultural production. A twofold increase in the irrigated cultivated land is observed in the last five decades (Foley et al., 2011). Irrigated rice alone utilized $25 \%-30 \%$ (about $45 \%$ in Asian countries) of surface water (IWMI, 2007; Ehrlich and Harte, 2015). Moreover, maintaining a regular water supply for crop irrigation is the major challenge (Millennium Ecosystem Assessment, 2005; Alroe et al., 2016). Thus, the variability in water availability induced by climate change is expected to further decrease the crop productivity in the near future, particularly for the rice crop (Du et al., 2015). Therefore, the wise use of water resources by developing proper irrigation management measures and improvement in crop water-use-efficiency is highly required (Yang and Zhang, 2010).

The capacity of soil to function as a living system in interaction with different components of the ecosystem is considered as the soil quality (Doran and Parkin, 1994). Further, soil organic carbon (SOC) is considered as the key indicator of soil quality (Lorenz et al., 2019) due to various ecosystem services provided by SOC such as soil structure maintenance, water retention properties, nutrient cycling via manipulating soil microbial communities (Smith et al., 2015). Globally, most of the agricultural land is facing the problems of soil acidification due to intensive $\mathrm{N}$-fertilizer use, soil erosion due to intensive tillage, nutrient imbalances due to intensive nutrient mining, loss of biological diversity by soil disturbance and agrochemical use resulted in considerable degradation in soil quality, crop productivity, and overall soil fertility (Srivastava et al., 2016a; Lal, 2020). The crop productivity is majorly determined by the concentration and availability of major nutrients in the soil matrix (Kumar et al., 2015; Srivastava

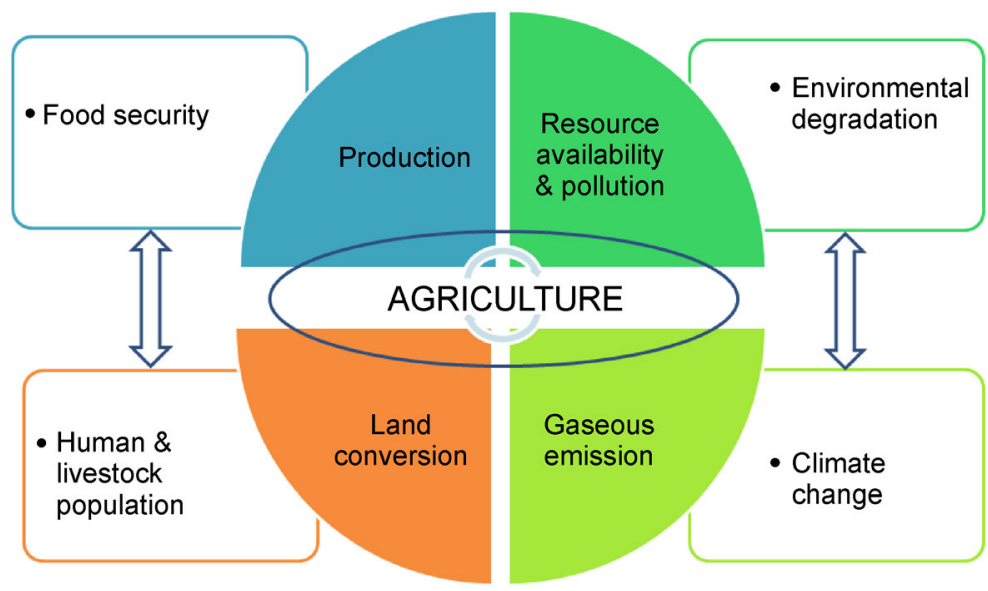

Fig. 1 An overview of integrated challenges majorly faced by the agriculture sector. 
et al., 2016b; Knapp and van der Heijden, 2018). Imbalances in the nutrient cycling and availability directly affect the soil quality (Lal, 2020). The deficiency of key nutrients required for different metabolic processes resulted in retarded growth of plants, and thus, decrease in crop yield (Gill and Tuteja, 2010; Antichi et al., 2019; Singh et al., 2020a). Injudicious use of chemical fertilizers supplies some essential elements whereas induces the extensive mining of other nutrients from soil system resulting in imbalances in nutrient availability with time. Thus, improvement in nutrient-use-efficiency (NUE) of plants for improving crop growth and yields is highly required (Gourley et al., 1994).

Nowadays, agriculture is recognized as one of the major contributors in GHGs emission (Burney et al., 2010). Agricultural systems along with related forestry and fisheries, and other land-use sectors (AFOLU) showed an almost twofold increase in total GHG emissions over the past 50 years (Smith et al., 2015). Agriculture sector shared about $17 \%$ of this increase in total GHG emission (IPCC, 2015). Among crops, paddy crop cultivation contributes the most GHG (mainly $\mathrm{CH}_{4}$ and $\mathrm{N}_{2} \mathrm{O}$ ) emission (IPCC, 2007; Hadi et al. 2010). Overall, the challenges for traditional agricultural practices associated with deteriorating resource quality and on-going climate change scenarios call for a set of modification in these practices which should strike the balance between the traditionally adapted knowledge and modern cultivation techniques (Srivastava et al., 2016a; Singh et al., 2019a).

\subsection{The need for resource-conservative agricultural practices}

In recent years, water scarcity and land degradation led to a considerable shift in agricultural practices. Now, there is a need to enhance crop yield with minimal environmental impact from the agricultural systems (Sharif, 2011). These shifts in agricultural practices are based on certain modification in traditionally-adapted agronomic practices. For example, Bhuiyan and Tuong (1995) suggested that maintaining a continuous water condition throughout the crop season is not necessarily required for paddy crop. Similarly, deep-tillage for crop cultivation is also not necessarily required. To maintain the agriculture production, improvement in soil biodiversity and health are the key factors for achieving sustainability in agriculture (Perfecto and Vandermeer, 2010; Chappell and LaValle, 2011; Lal, 2020). Ecological health can only be restored by adopting judicious resource utilizing agricultural practices (Barea, 2015; Srivastava et al., 2016a). This can be possible by including some practices like the application of biofertilizers and related microbial inoculants, and increased inputs of organic matter to the agricultural system having greater compatibility for the long-term. Based on the assumptions, outlined in Fig. 2, to overcome the environmental challenges for the agricultural sector, several practices have emerged which are elaborated in the following paragraph.

Major agronomic practices such as conservation agriculture for managing soil health (Kassam et al., 2009); the

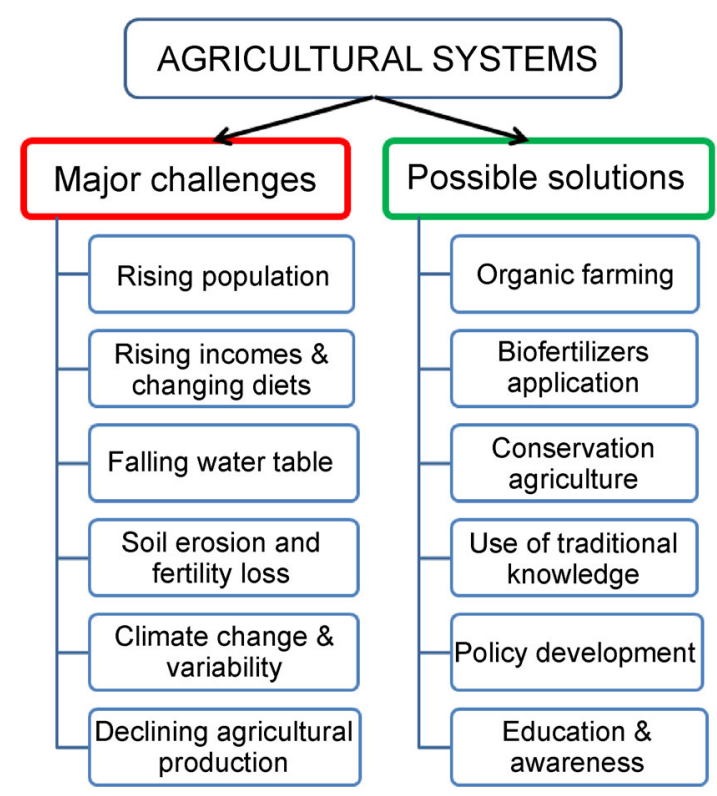

Fig. 2 An illustrative representation of major challenges for traditional agriculture and possible mitigation measures by adapting emergent agronomic practices.

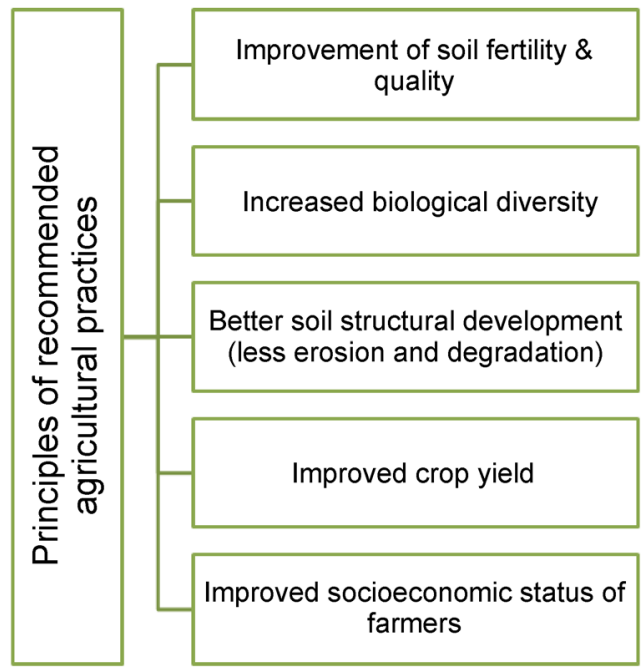

Fig. 3 Basic principles underlying for the development of emergent agronomic practices for attaining agricultural sustainability.

system of rice intensification (SRI) and aerobic rice cultivation for reducing water consumption and GHG emissions from paddy fields; deficit irrigation, drip irrigation, mid-season drainage for improving water-use-efficiency; and biofertilizer and organic soil ameliorant for managing soil fertility (Delgado et al., 2011; Thierfelder et al., 2017) have been emerged for achieving agricultural sustainability. Conservation agriculture, the SRI, organic farming and soil amendment based agriculture can be considered as a better practice to fulfil the objectives proposed by the IRRI for resource management under climate change scenario (Choi et al., 2013). These 
systems are based on several principles, outlined in Fig. 3, for the sustainable natural resource management without compromising crop production (Knowler and Bradshaw, 2007; Mishra et al., 2013; Lal, 2015; Knapp and van der Heijden, 2018). Since these agronomic practices are still considered as 'work in progress' practices due to their versatility to adapt new changes best suited for site-specific real-time experiences (Kassam and Brammer, 2016), they can be further considered as emergent agronomic practices. Thus, the objectives of this review were to: (1) identify the research progression in different emergent agronomic practices, (2) assess the environmental impacts, and (3) explore the potential of different practices for developing the agronomic packages, for agro-ecological balance and climate change adaptation.

This review is a step toward understanding the development in emergent agronomic practices. The overall focus is on understanding the combined application of agricultural techniques, however, to do that, we applied the bibliometric tools to analyze the state of research for different emergent agronomic practices. Conservation agriculture, the SRI and soil amendment based agronomic practices were examined with respect to the literature addressing climate change and nutrient cycling. As described in the next section, research into emergent agronomic practices has yet to exploit the benefits of a combined approach for developing packagebased agricultural systems.

\section{Bibliometric analysis: methodology}

The documents indexed in the Web of Science (core collection) database from 2005 till 21st January 2021 were considered to ascertain the trend of research. In the first step, three searches were conducted using the terms "conservation agriculture," "system of rice intensification" and "soil amendment" following the structured approach of Cobo et al. (2011) and Yadav et al. (2021). Results of each search were refined for "climate change" OR "nutrient cycling." In the case of "soil amendment" results, an additional step was added before the final search by adding "biochar" OR "biofertilizer" OR "organic manure." The final results for each of the three searches have been referred to by conservation agriculture, system of rice intensification and soil amendment, respectively. We used the "bibliometrix" package in R (ver. 4.0.2) for bibliometric analysis (Aria and Cuccurullo, 2017). The keyword-plus (ID) term from the Web of Science search results was used for the bibliometric analysis. ID is a unique feature of the Web of Science database where the articles are tagged with predefined research areas according to the references cited in the article. The IDs are different from the author's keywords; hence provide a consistent and contextual basis of assessment.

Keyword co-occurrence network plot and thematic evolution plots were used for analyzing the results. In the keyword co-occurrence plot, the circles (nodes) represent a collection of themes named by the most frequent ID, and the connecting lines (edges) represent their linkages. A very frequent and interlinked theme has a larger node and more edges. Similar nodes form a cluster which is denoted by a color. Each cluster is usually referred to by the name of its largest or the most linked node. Further, thematic evolution analysis was performed to identify the research trends for different agricultural practices. For thematic evolution analysis, the time was divided into two major classes as (1) representing the research trend in last five years, and (2) showing the research trend since the emergence of a particular research field (e.g., 2004-2016 for conservation agriculture, 2009-2016 for SRI, 2010-2014 for soil amendments). Thematic evolution analysis revealed the evolution of different themes with the time and their segregation or aggregation with other related themes under different periods. Moreover, this analysis also helps in identifying the emerging themes for a particular research topic.

In addition to the above-mentioned bibliometric analyses, another literature survey was performed using Web of Science and Scopus database for exploring the research progression on combined agricultural practices. Different keywords (e.g., conservation agriculture, system of rice intensification, biochar, organic agriculture, organic farming, and biofertilizer) were used in different combinations to identify the studies dealing with the combined application as the core objective of this study (Table 1). Based on the search results, relevant literature dealing with the combined application of different agronomic practices were mined for identifying the compatibility of different practices to develop agriculture packages for particular agro-ecosystems.

\section{Emerging agronomic practices: research trends}

Based on the Web of Science search results (refined by "climate change" OR "soil fertility") of three different emergent agronomic practices, the climate change and nutrient cycling refined results for both conservation agriculture (Fig. 4A) and SRI (Fig. 5A) showed an interlinked pattern whereas there was lesser interconnection between thematic areas in soil amendment results (Fig. 6A). A detailed description of the keyword co-occurrence and thematic evolution analyses has been given in the following sub-sections for different emergent agronomic practices.

\subsection{Conservation agriculture}

Conservation agriculture is based on the principle of integrated crop and soil management practices such as reduced or no soil disturbance, permanent soil cover by residue retention and crop rotation or multiple cropping systems (Thierfelder et al., 2017). These principles are based on in situ conservation of SOM and later lead to soil carbon sequestration (Lal, 2004, 2015, 2020). Residue 
Table 1 Number of studies found in the bibliometric analysis results for the combined application of different agricultural practices from the Web of Science (Core Collection) and Scopus databases (searched on $21^{\text {st }}$ January 2021).

\begin{tabular}{|c|c|c|c|}
\hline \multirow[t]{2}{*}{ S.N. } & \multirow[t]{2}{*}{ Search words (Agronomic practice keywords) } & \multicolumn{2}{|c|}{$\begin{array}{l}\text { Number of studies in } \\
\text { different database }\end{array}$} \\
\hline & & Web of Science & Scopus \\
\hline 1 & "conservation agriculture" AND "organic farming" & 39 & 41 \\
\hline 2 & "conservation agriculture" AND "organic agriculture" & 27 & 21 \\
\hline 3 & "biochar" AND "organic farming" & 21 & 52 \\
\hline 4 & "conservation agriculture" AND "biochar" & 20 & 21 \\
\hline 5 & "conservation agriculture" AND "system of rice intensification" & 12 & 12 \\
\hline 6 & "conservation agriculture" AND "soil amendment" & 5 & 20 \\
\hline 7 & "system of rice intensification" AND "organic farming" & 5 & 10 \\
\hline 8 & "biochar" AND "organic agriculture" & 4 & 8 \\
\hline 9 & "system of rice intensification" AND "organic agriculture" & 2 & 2 \\
\hline 10 & "conservation agriculture" AND "system of rice intensification" AND "organic agriculture" & 2 & 2 \\
\hline 11 & "conservation agriculture" AND "biofertilizer" & 1 & 5 \\
\hline 12 & "system of rice intensification" AND "biochar" & 1 & 3 \\
\hline 13 & "system of rice intensification" AND "soil amendment" & 1 & 2 \\
\hline 14 & "conservation agriculture" AND "system of rice intensification" AND "biochar" & 0 & 0 \\
\hline
\end{tabular}

retention policy in conservation agriculture reduces crop residue burning and related environmental pollution simultaneously with the improvement in soil properties (Kassam et al., 2015). Moreover, conservation agriculture principles help in reducing soil degradation and improve crop yield (Thierfelder et al., 2017; Singh et al., 2019a).

Based on keyword co-occurrence analysis, three clusters were identified which were dominated by conservation agriculture, climate change and management (Fig. 4A). The co-occurrence plot indicated the importance of Indo-Gangetic plains, carbon sequestration, greenhouse gas emissions, systems and food security in the conservation agriculture cluster. Management approaches were aimed at organic matter and SOC sequestration. From the perspective of climate change, the role of organic carbon and ecosystem services was one of the subject areas of conservation agriculture research. Presence of Sub-Saharan Africa in the climate change cluster and Indo-Gangetic plains in the conservation agriculture cluster highlighted the importance of these regions in conservation agriculture research.

The thematic evolution plot showed the evolution of different research areas in conservation agriculture for the 2004 to 2021 period (Fig. 4B). Interesting to note was the fact that during the 2004-2016 period, the yield was the major focus of research, whereas during the 2017-2021 period, conservation agriculture itself evolved as the major focus. During the 2017-2021 period, conservation agriculture was studied from the perspective of Africa, maize, water-useefficiency, northern Ethiopia, biodiversity, management and yield. The impact of tillage and organic matter also occupied a prominent position during the 2017-2021 period, indicating their significance in the evolving research. Gradual identification of conservation agriculture as the agronomic practice to maintain soil nutrient cycles and mitigate the impact of climate change was found to be increasingly recognized, as evident in the thematic evolution.

\subsection{The system of rice intensification (SRI)}

The SRI is based on certain modified principles from the traditionally adapted rice cultivation methods such as 10-12 days young seedlings transplantation, 1-2 seedlings per hill, wider spacing between two hills, intermittent or minimal irrigation only for saturating the soil, use of mechanical weeder and increased proportion of organic fertilization (Uphoff et al., 2011). The SRI is reported to improve crop yield and water productivity (CIIFAD, 2014; Thakur et al., 2014; Deelstra et al., 2018).

Research in the SRI, from the perspective of climate change and nutrient cycling evolved into three clusters in the keyword co-occurrence analysis (Fig. 5A). Food security and resource-use-efficiency were found to be the dominating themes in the climate change cluster. The SRI cluster included the socio-economic aspects of management practices like household income, technology, opportunities and intensification. The SRI node was quite small but highly interlinked with other thematic areas. This indicated that application of the SRI has been frequently cited but research into its various aspects is still in nascent stage from the perspective of climate change and nutrient cycling. 
A

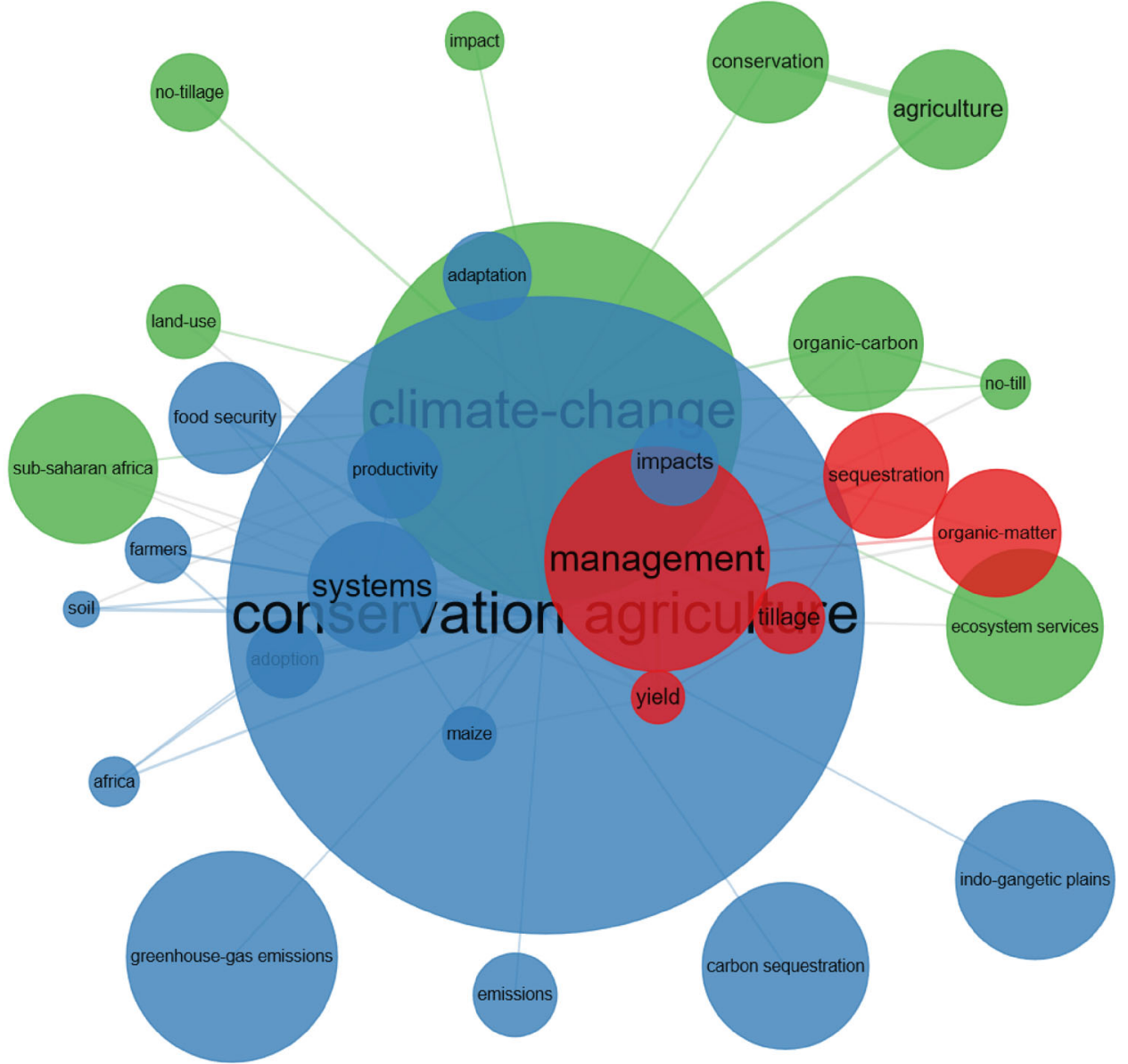

B

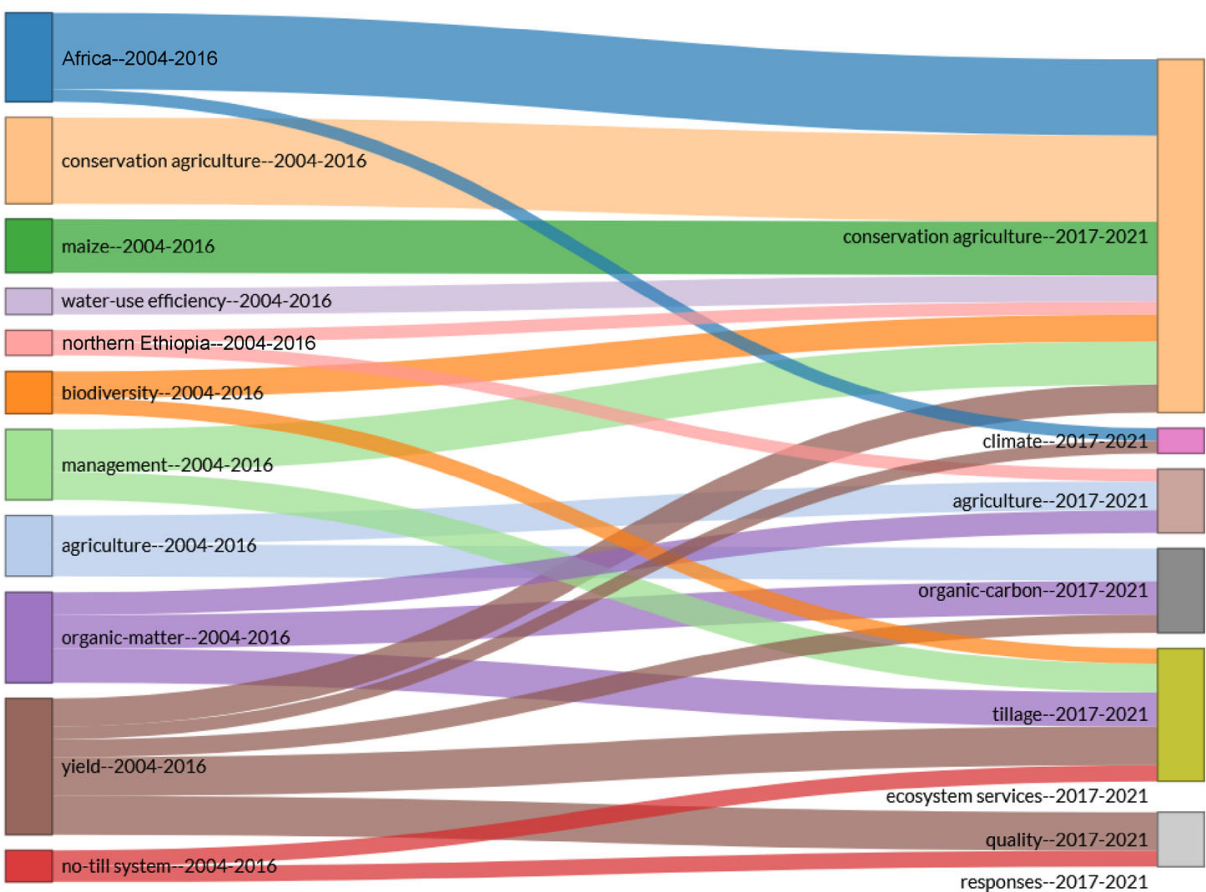

Fig. 4 Keyword co-occurrence network plot (A) and thematic evolution plot (B) for search results of "conservation agriculture," refined with "climate change" AND "nutrient cycling" from the Web of Science (searched on 21st January 2021). 
A

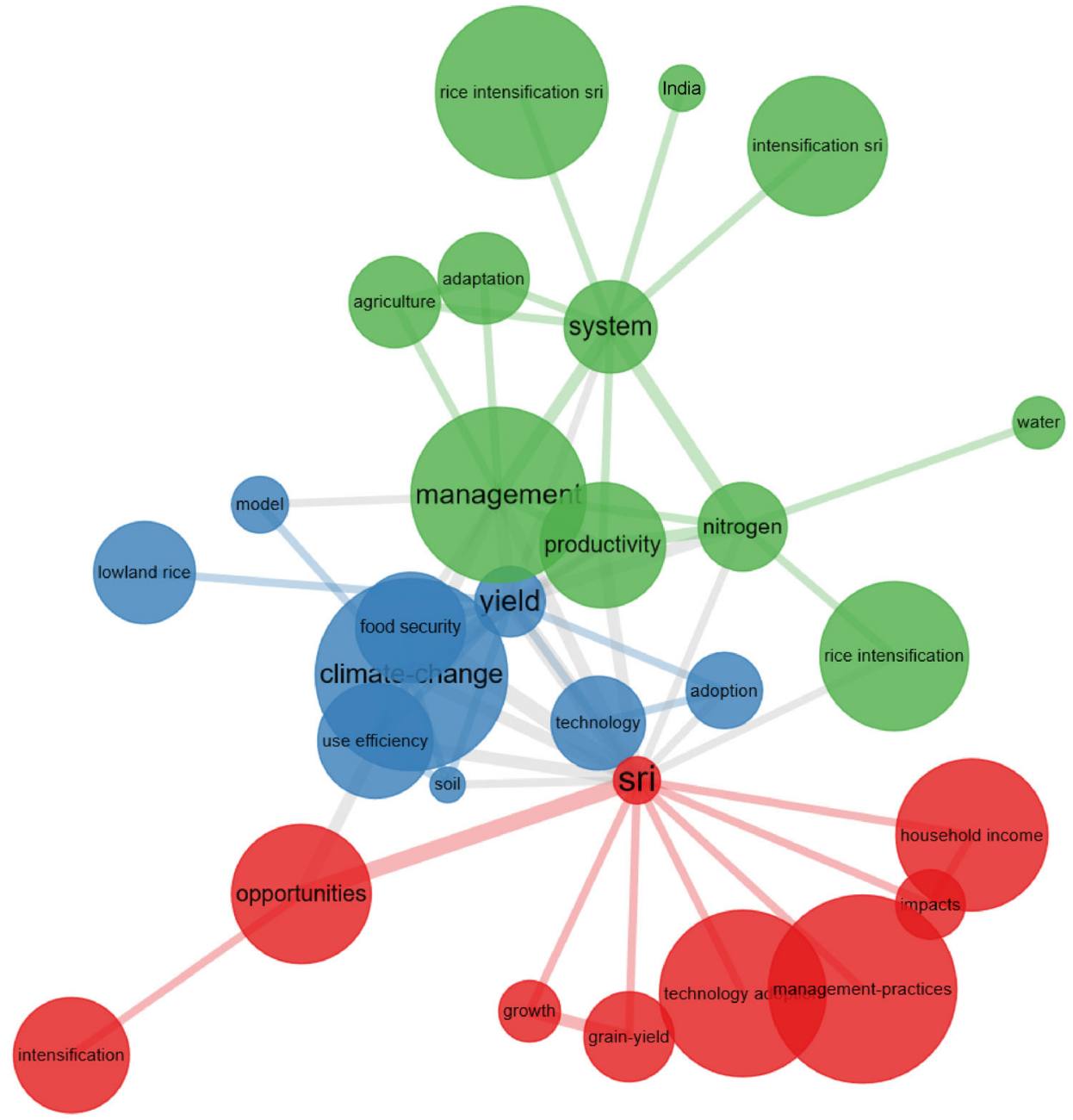

B

\section{growth--2009-2016}

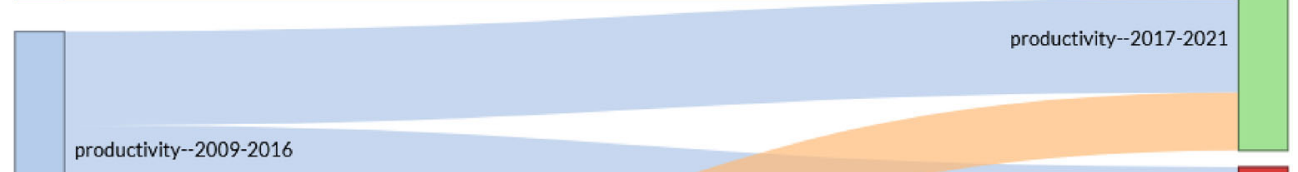

productivity-2009-2016

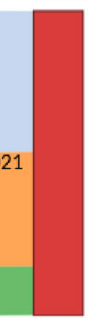

system--2009-2016

sri-2017-2021
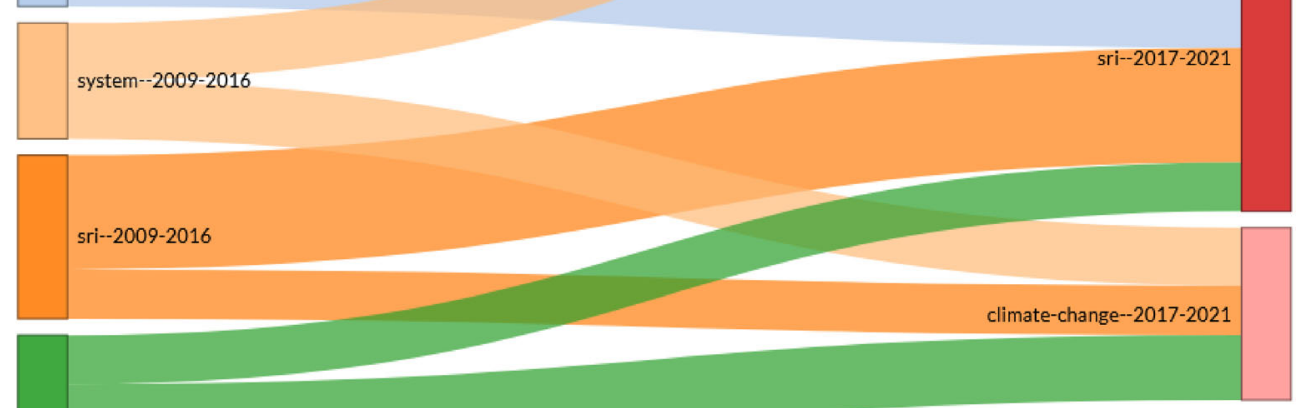

yield--2009-2016

agricultural technology--2017-2021

greenhouse-gas emissions--2017-2021

nitrogen--2017-2021

Fig. 5 Keyword co-occurrence network plot (A) and thematic evolution plot (B) for search results of "system of rice intensification," refined with "climate change" AND "nutrient cycling" from the Web of Science (searched on 21st January 2021). 

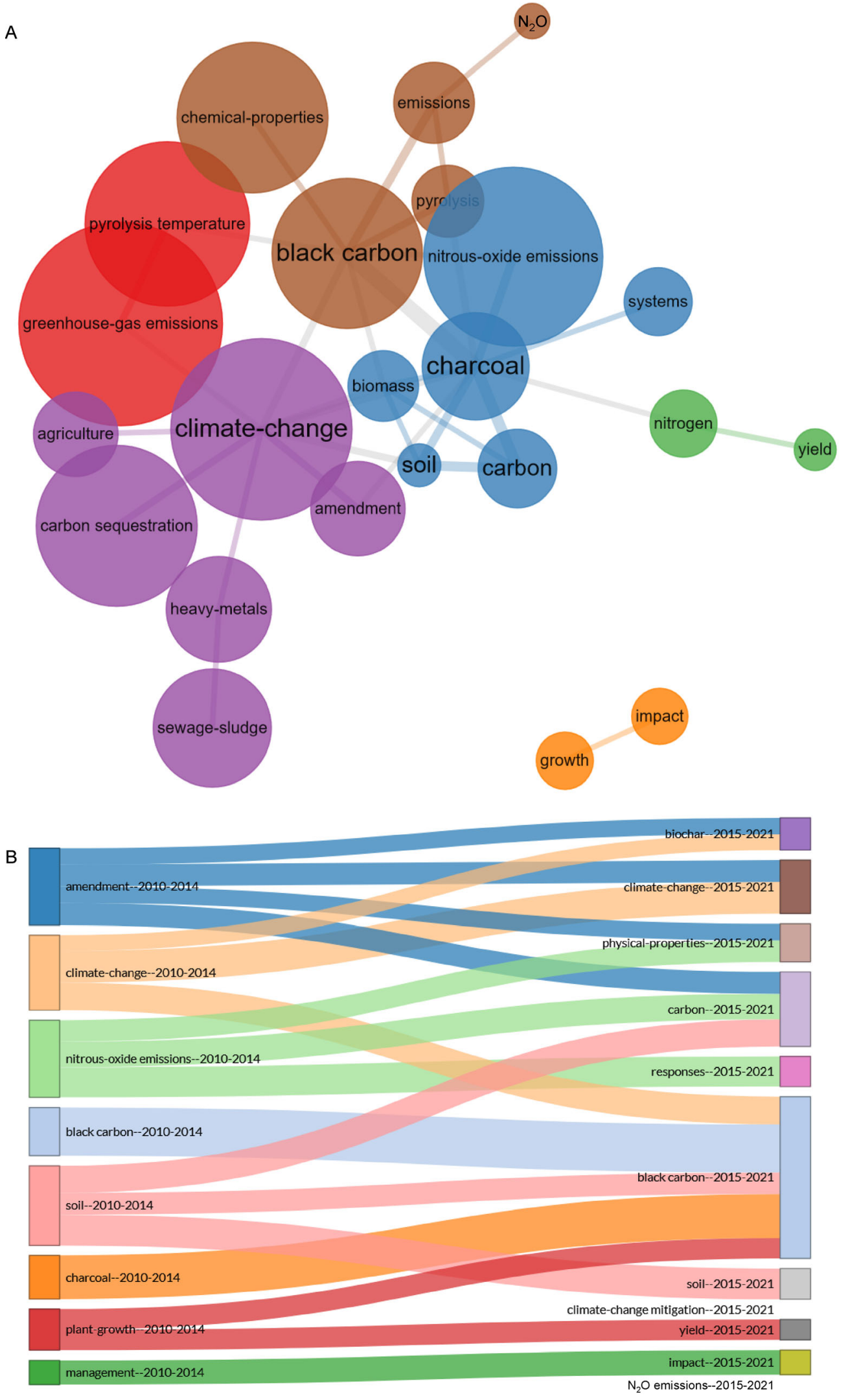

Fig. 6 Keyword co-occurrence network plot $(A)$ and thematic evolution plot (B) for search results of "soil amendment," refined with "biochar," "biofertilizer," "organic manure," "climate change" AND "nutrient cycling" from the Web of Science (searched on 21st January 2021). 
Thematically, yield and productivity were the focus of research in the SRI during initial (2009-2016) period of its emergence (Fig. 5B). There was a general diversification of themes from 2009 to 2021 period with the emergence of climate change, agricultural technology, greenhouse gas emissions and nitrogen as thematic areas during 20172021. Though the literature on the SRI was available from 2009 , it increased during the considered time. Research focus has been increased into the role of the SRI in nutrient cycling and climate change mitigation during the 2009-2021 period (Fig. 5B).

\subsection{Soil amendments (biochar, biofertilizer and organic} manure)

Organic farming helps in increasing soil organic matter (SOM) content which further improves soil quality and fertility (Srivastava et al., 2016a; Singh et al., 2019a). Further, a surplus amount of crop residues are openly burnt in the field which leads to soil nutrient loss and environmental pollution (Singh and Sidhu, 2014). Biochar has been extensively suggested for waste management and reducing crop residue burning (Singh et al., 2015). Similarly, biofertilizer (or microbial consortium) application has nowadays been recommended for restoring soil health and productivity for attaining sustainability in agriculture (Kumar and Verma, 2018). However, most of the researches on soil amendments are isolated or restricted to a particular theme e.g., soil fertility or climate change mitigation approaches. The keyword co-occurrence plot for soil amendments also showed very few linkages and six clusters, indicating the isolated nature of developments into climate change and nutrient cycling aspects (Fig. 6A). The climate change cluster included carbon sequestration, and it was also studied with respect to heavy metals and sewage sludge. This was possibly due to multifaceted application of biochar for improving soil fertility, C sequestration, pollutant remediation and waste management (Singh et al., 2015). Though the themes were found isolated, however, carbon sequestration, greenhouse gas emissions, nitrous-oxide emissions, black carbon and pyrolysis temperature dominated the plot. All these keywords are mainly related to biochar research which revealed the diversification of biochar research among different soil amendments. The thematic evolution of climate change, black carbon, soil, charcoal and plant growth into black carbon (biochar) indicated their significance in soil amendment research (Fig. 6B). The role of biochar in mitigating climate change can be ascertained from the position of black carbon and biochar during the 2017-2021 period.

Based on the results of bibliometric analysis, it can be inferred that the research on emergent agronomic practices for improving soil fertility and climate change mitigation are emerging with the time. The thematic evolution plots for all the three major practices revealed the research trend toward the yield and productivity, resource-use-efficiency and physical development of soil, and GHG emissions and climate change mitigation in the recent five years. In the next section, detailed insight into the environmental impacts of different emergent agronomic practices has been given.

\section{Environmental impacts of emergent agronomic practices}

Recently, Garbach et al. (2017) reviewed 104 studies with contrasting farming practices and found that the SRI, conservation agriculture and precision agriculture-based agronomic practices showed 'win-win' or 'win-neutral' responses for both yield and ecosystem services. The environmental impacts of a few highly recommended emergent agronomic practices adopted in the tropical agroecosystems have been outlined in the following sub-sections.

\subsection{Soil properties}

Improvement in root zone soil aeration is observed under the SRI due to wider spacing between hills, minimal water use for irrigation and cono-weeding practices (Uphoff et al., 2011; Dass et al., 2015). Kumara et al. (2016) observed that aerobic conditions, intermittent irrigation and organic amendments in the SRI led to the increase in soil $\mathrm{pH}$, increase in SOC and soil $\mathrm{N}$ contents as compared to the traditional agronomic practices. Increased soil $\mathrm{N}$-availability in the root zone is reported in the SRI method due to higher biological $\mathrm{N}$-fixation under aerobic conditions or availability of $\mathrm{N}$ from heterogeneous sources applied in the soil (Das et al., 2018). Higher microbial biomass, enzyme activities and root growth parameters were observed in the SRI-rice cultivation method as compared to the traditional agronomic practices (Rupela et al., 2006), particularly during the post-rainy season (Thakur et al., 2010).

Conservation agriculture practices with full adoption conditions (three principles) have been reported to have considerable effects on different soil properties (Lal, 2008; Sapkota et al., 2012; Lienhard et al., 2013). A decrease in soil bulk density (at 15-20 cm soil depth) was reported in conservation agriculture applied organic matter-rich soils (Khorami et al. 2018; Kumar et al., 2019). However, an increase in surface soil bulk density was also reported during the initial years of conservation agriculture adopted fields (Khorami et al., 2018; Jat et al., 2019). Reduced mechanical disturbance and increased organic matter inputs in conservation agriculture lead to improved soil structure and erosion control (Abdalla et al., 2013; Seitz et al., 2019). Residue retention and reduced-tillage practices improved soil moisture and $\mathrm{N}$ availability (Peter, 2018; Parihar et al., 2019). The tillage practices affect the soil aggregate dynamics and related biological activity (Reeves et al., 2019). Significant increase in SOC, soil N, dissolved organic $\mathrm{C}$, microbial biomass and community composition was reported under conservation agriculture system (Wang et al., 2011; Guo et al., 2015, 2016; Zhao et al., 2016; Khorami et al., 2018). However, a decrease 
in available $\mathrm{N}$ content on the soil surface was also observed due to $\mathrm{N}$-immobilization in the crop residue and microbial biomass (Khorami et al., 2018; Singh, 2019). Crop residue retention along with reduced-tillage facilitate the movement of SOC and soil $\mathrm{N}$ to the deeper soil layers and reduce the rate of residue decomposition in the top layer by providing suitable micro-environmental conditions (Gathala et al., 2011; Kumari et al., 2011; Khorami et al., 2018; Jat et al., 2019). Moreover, planting of leguminous crops under crop rotation policy of conservation agriculture improves soil porosity and nutrient availability (Kassam and Brammer, 2013; Partey et al., 2016).

Organic amendment to soil showed improvement in SOC level which resulted in improved SOC dynamics, and therefore, regular organic amendments are recommended for improving soil vitality and nutrient pools (Lal, 2013; Srivastava et al., 2016b; Knapp and van der Heijden, 2018; Singh et al., 2019a, 2019b). Mishra et al. (2006) found that soils receiving organic amendments stimulate the growth-promoting soil bacteria proliferation. Biochar application leads to improvement in soil structure and nutrient absorption potential (Wang et al., 2016). Qu et al. (2014) reported a decrease in soil bulk density and an increase in soil moisture content after a ricehusk ash application. Combined application of biochar with other organic amendments (e.g., organic manure, crop residue) was also reported to improve soil WHC, moisture content, soil $\mathrm{pH}$, electrical conductivity and soil nutrients (Kameyama et al., 2016; Singh et al., 2019b, 2019c). The high cation exchange capacity of biochar reduces nutrient leaching and increases nutrient availability in the root zone which resulted in increased seed germination, plant growth, and crop yield (Sparrevik et al., 2013). Sole biochar application was reported to inhibit $\mathrm{N}$-mineralization rate by reducing ammonification and nitrification processes (Granatstein et al., 2009; DeLuca et al., 2015). On the contrary, increased nutrient availability was reported under combined biochar and compost applied soils (Fischer and Glaser, 2012; Schulz and Glaser, 2012; Singh et al., 2019b). Several studies reported higher microbial community growth and microbial biomass under biochar amended soils (Biederman and Harpole, 2013; Wang et al., 2016). The high surface area, porous quality and higher availability of inorganic nutrients on the biochar surface provide a favorable niche for microbial growth and proliferation (Warnock et al., 2010). Thus, emergent agronomic practices have considerable potential to improve soil quality and nutrient dynamics.

\subsection{Water resource utilization}

Several studies reported a reduction in irrigation water use under the SRI and conservation agriculture systems of rice and wheat cultivation which further led to the improvement in water-saving and crop water productivity (Pascual and Wang, 2017; Das et al., 2018; Khorami et al., 2018; Li et al., 2018; Jat et al., 2019). During low rainfall years, the SRI performance was found better, though the water-saving and crop water productivity was found slightly lower as compared to the high rainfall years (Raj et al., 2017). Das et al. (2018) found considerably higher crop water productivity under locallymodified SRI practices. Jat et al. (2019) reported 67\% higher total water productivity under conservation agriculture-based rice-wheat-mungbean cropping system as compared to the traditional management system. Das et al. (2016) also observed higher crop water productivity for the second and third year of experimentation under conservation agriculture system as compared to the traditional agronomic practices applied in the pigeon pea-wheat cropping system. The residue retention in conservation agriculture system improves the soil moisture content and reduces evaporation loss which leads to reduced water requirement and increased crop water productivity. The studies performed in the arid regions showed that biochar amendment either sole or in combination with other organic ameliorants improve the soil hydro-physical properties such as porosity, water-filled pore space and water holding capacity which further improves crop water productivity (Agbna et al., 2017; Li et al., 2018; Singh et al., 2019c). However, occasional yield penalty in sole biochar applied soils due to nutrient immobilization and water scarcity may lead to lower crop water productivity under biochar application (Faloye et al., 2019).

\subsection{Greenhouse gas emission}

Greenhouse gas emission varies with soil type, soil $\mathrm{pH}$, temperature, soil moisture, SOC content, nutrient and water management, crop types and growth stages. Therefore, precise recommendations are difficult to provide under different agricultural management practices (Thakur and Uphoff, 2017). A net reduction in GHGs emission in terms of their global warming potential (GWP) is reported in the SRI practices due to aerobic conditions (Suryavanshi et al., 2013; Thakur et al., 2014). Conservation agriculture practices have been reported to reduce GHGs emission from the intensively cultivated areas (Ceja-Navarro et al., 2010). However, an increase in $\mathrm{CO}_{2}$ emission due to decomposition of crop residues (Oorts et al., 2007; Peter, 2018) and a decrease in $\mathrm{CO}_{2}$ due to reduction in tillage activities and residue burning were observed under different studies (Alluvione et al., 2009; Lal, 2013; Abdalla et al., 2016). Singh et al. (2009) also observed higher cumulative soil $\mathrm{CO}_{2}$ efflux from the wheat straw and Sesbania + wheat straw applied treatments, however, the release of $\mathrm{CO}_{2}$ per unit of SOC was found comparatively lower. It showed the SOC sequestration potential of conservation agriculture system. According to the estimates of FAO (2008), adoption of conservation agriculture-based best management practices may help in sequestering $1.8 \mathrm{tCO}_{2} \mathrm{ha}^{-1} \mathrm{yr}^{-1}$. Therefore, a detailed analysis of different climatic and edaphic conditions should be kept in mind while recommending conservation agriculture for a region (Kirkegaard et al., 2014; Reeves et al., 2019). Singh et al. (2009) and Srivastava et al. (2018) reported higher soil $\mathrm{CO}_{2}$ efflux from organic amendment applied plots, but the soil $\mathrm{CO}_{2}$ efflux released per unit of SOC was considerably 
lower for the organic amendment as compared to the chemical fertilizer applied soils. It revealed the high $\mathrm{C}$ sequestration potential of organic amendment applied soils in the long term, and therefore, it needs further assessment.

Overall, different emergent agronomic practices lead to an improvement in soil quality/health and crop productivity, decrease in water use and GHGs emission (with some exceptions) from the major cropping systems. However, there is a need to assess the complementary behavior of different emergent agronomic practices when applied in combination. A brief account of the compatibility parameters of different emergent agronomic practices is presented in the next section.

\section{Compatibility assessment of emergent agro- nomic practices for agro-ecological balance and climate change adaptation}

Substantial research is being done with respect to agricultural land management practices at the global scale for exploring the ecological aspects of agriculture (Kassam and Brammer, 2016). As mentioned earlier, environmental implications of a few emergent agricultural practices such as the SRI, conservation agriculture and organic amendments in agricultural fields have been widely explored (Sharif, 2011; Kassam and Brammer, 2016). The bibliometric analysis results for different combined emergent agronomic practices revealed the following trend: conservation agriculture + organic amendment > biochar + organic amendments > conservation agriculture + biochar > conservation agriculture + SRI>SRI + organic amendments (Table 1 ). These results revealed that conservation agricultural practices have more compatibility to incorporate soil amendments (organic, biofertilizer and biochar) as well as SRI practices. Our in-depth literature review identified 18 studies (12 experimental, 4 review and 2 meta-analysis) which were directly dealing with the combined application of emergent agronomic practices (viz., conservation agriculture, SRI, organic farming and biochar) for exploring the impacts on soil biophysical properties, plant performance and yield, and climate change mitigation (Table 2). Interestingly, out of 18 studies, 13 studies have been published in the last three years (3 in 2018, 5 in 2019 and 5 in 2020) which revealed the emergence of the topic in the last few years. Moreover, this trend analysis also revealed that we may witness a number of studies dealing with the combined agronomic practices in the coming years.

Basic principles of the emergent agronomic practices i.e., preserving the natural resources while producing at par crop yield, remain same (Sharif, 2011). This indirectly revealed their complementarity for each other (Kassam and Brammer, 2016). Recently several studies emphasized on the integration of most of these practices and exploration of the environmental implication of an agronomic package for an agro-ecosystem (Sharif, 2011; Kassam and Brammer, 2013 ,
2016; Knapp and van der Heijden, 2018; Peter, 2018). The bibliometric analysis results for a combination of "conservation agriculture" AND "system of rice intensification" yielded 12 documents with 61 ID in Web of Science. The keyword cooccurrence plot revealed the formation of three clusters mainly dominated by conservation agriculture (Fig. 7). The other two clusters represent the socio-economic (opportunities and farmers; and rotation, performance and agriculture) aspects of the combined conservation agriculture and the SRI practices.

Kassam and Brammer (2013) suggested that the combination of the SRI with conservation agriculture may further improve the rice-wheat crop performance by providing onfarm inputs and suitable environmental conditions to the plants (Table 2). The massive size of the conservation agriculture node which was in close interaction with the SRI (and system intensification) node represent that research communities are focusing on the integration of SRI in on-going conservation agriculture practices which provide opportunities for better adoption by the farmers and improves the performance and resource-use-efficiency (Fig. 7). The combination of the SRI with conservation agriculture has been termed as the 'paradoxical agriculture' which enables the farmers to obtain more output with less input (Sharif, 2011). The high level of organic matter on the top soil may improve the soil biological activities which help in developing the feedback mechanism of any system (Kassam et al., 2011). Thus, incorporation of organic farming with SRI-conservation agriculture system may further provide long-term benefits to the whole system by improving soil, water and human health (Sharif, 2011; Garbach et al., 2017). Sharif (2011) and Uphoff et al. (2011) reported about the effort being made for integrating SRI with conservation agriculture in the IndoGangetic Plains of Pakistan, and the preliminary results showed positive responses. Similarly, incorporation of some similar approaches in the Jiangsu Province of China has been also reported (Zhang and Lu, 2010). Studies of Khadka and Uphoff (2019), Singh (2019) and Singh et al. (2020b) also reported the at par system yields for rice-wheat cropping system following the organic-SRI-conservation agriculture combined packages. Though, yield penalty for individual crops were also observed in these studies.

Biochar application to the conservation agriculture has been suggested to improve the soil biophysical properties which may help in better crop performance in degraded soils (Peter, 2018; Singh, 2019; Nyambo et al., 2020a), and hold substantial significance under the present climate change scenario (Sparrevik et al., 2013; Nyambo et al., 2020b). Based on the meta-analysis results on 193 studies on organic farming and conservation agriculture application with 2896 comparisons, Knapp and van der Heijden (2018) reported temporal stability $(-3 \%)$ in crop yield for the transition between tilled and no-tilled cropping system. Knapp and van der Heijden (2018) further suggested that the integration of organic inputs in conservation agriculture systems may 


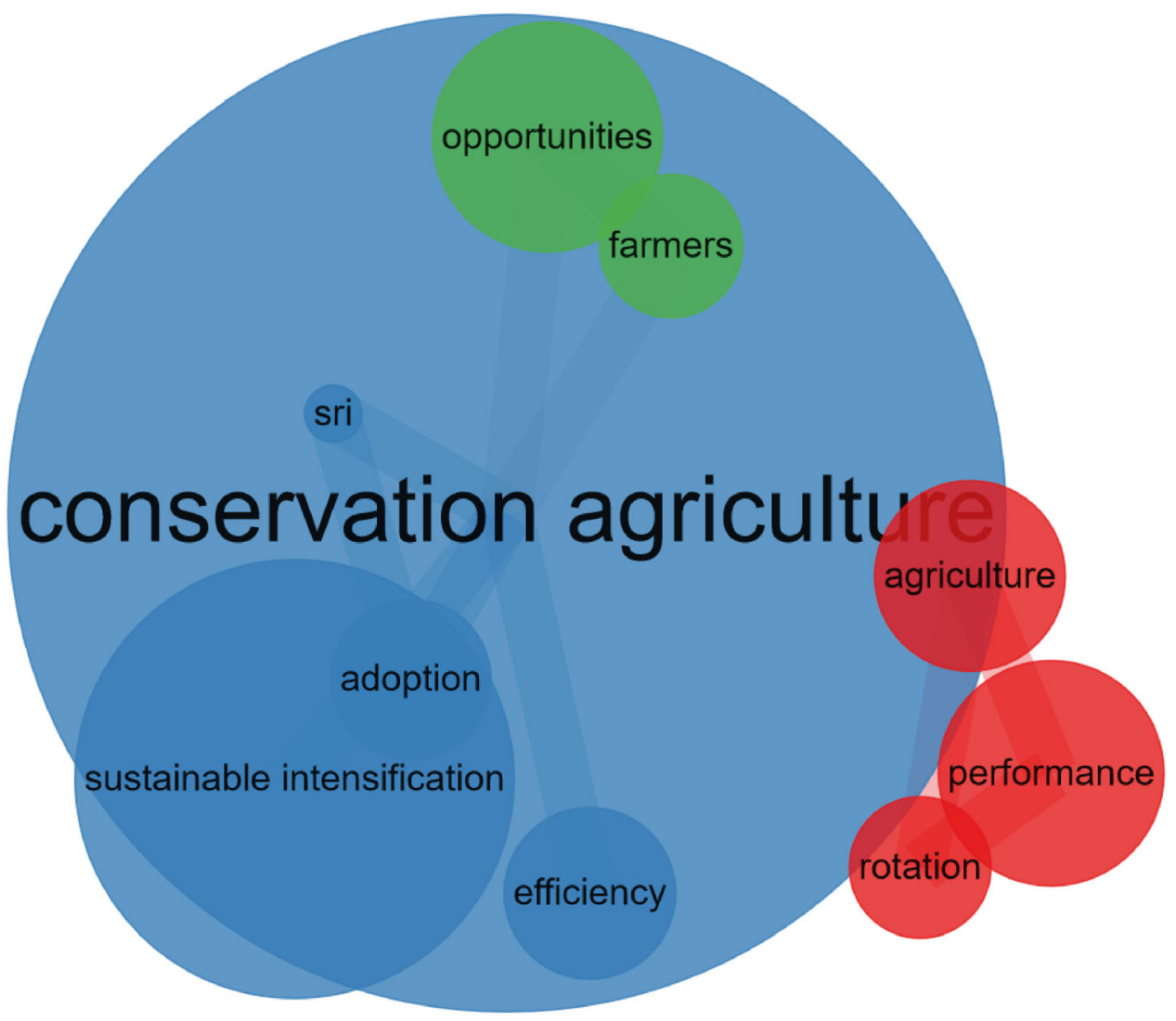

Fig. 7 Keyword co-occurrence network plot for search results of "conservation agriculture" AND "system of rice intensification" from the Web of Science (searched on 21st January 2021).

improve the crop yield and minimize the yield gaps. Incorporation of biochar in different emergent agronomic practices enhances the nutrient retention capacity, reduces the GHGs emission and nourishes the soil biological activities which increases the overall soil fertility and crop yields (Partey et al., 2016; Singh et al., 2019b; Nyambo et al., 2020a,b).

The benefits and risks associated with the adoption of compatible agriculture package in different climatic conditions have been elaborated in Table 2 . The outcome of the literature survey revealed that the emergent agronomic practices (conservation agriculture, the SRI, organic agriculture and biochar/biofertilizer amendment) have considerable compatibility to be used in a package for attaining agricultural sustainability. Kassam et al. (2011) suggested some key questions be asked in terms of compatibility of two agronomic practices for a particular soil-climate system before applying the integrated farming approach for any agro-ecosystem. Some limitations and challenges may be observed during the initial phases of adoption of compatible agronomic packages. Thus, compatibility assessment of different agricultural practices and their suitability for a particular agro-climatic zone should be emphasized in the future agricultural researches for developing climate-smart agricultural packages.

\section{Challenges and limitations for the adoption of compatible agriculture packages}

The combined application of different emergent agronomic practices although provide several ecosystems services, however, some criticisms and negative consequences have also been reported in the literature. For example:

(i) The climatic variability in terms of precipitation and temperature regimes have been considered as the major challenge for developing compatible agriculture packages (Campiglia et al., 2015). The variation in precipitation regulates the nutrient (especially $\mathrm{N}$ ) availability, and thus, the crop performance and yield under sole organic inputbased emergent agronomic practices (Campiglia et al., 2015; Cooper et al., 2016; Singh et al., 2019c).

(ii) No-tillage in conservation agriculture and minimizing the puddling in SRI may create hardpans in the surface layer during the initial years due to movement of heavy agricultural vehicles. The hardpan may restrict the soil aeration, root penetration and microbial activities after subsequent farming. However, this can be overcome after a few years of adoption due to crop residue retention, its decomposition and maintenance of sufficient organic matter content on the surface by improved microbial activities when minimal tillage is applied 


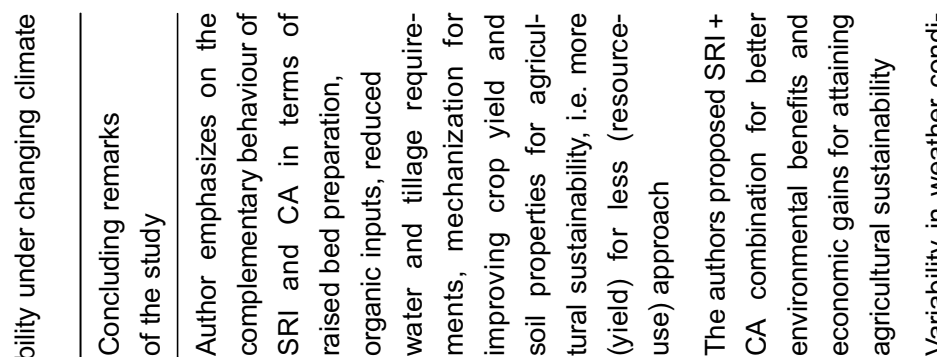

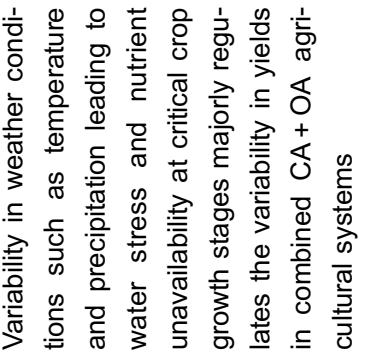

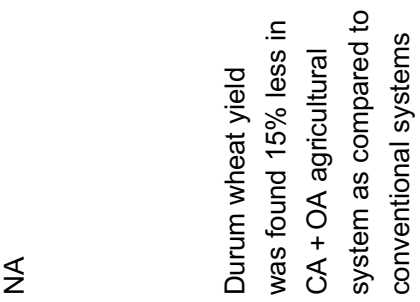

$\varangle$

恋

$$
\begin{aligned}
& \frac{4}{2} \\
& \frac{0}{20} \\
& \frac{0}{0} \\
& \frac{0}{0}
\end{aligned}
$$

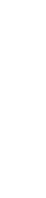$$
\text { 石 }
$$$$
\text { (2) }
$$

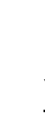$$
\text { (⿻日土一) }
$$$$
\text { ( }
$$ 


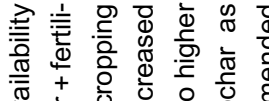

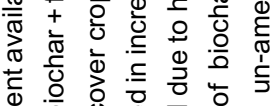

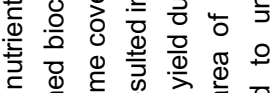

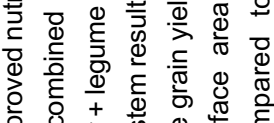

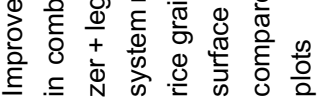

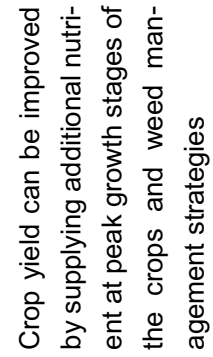

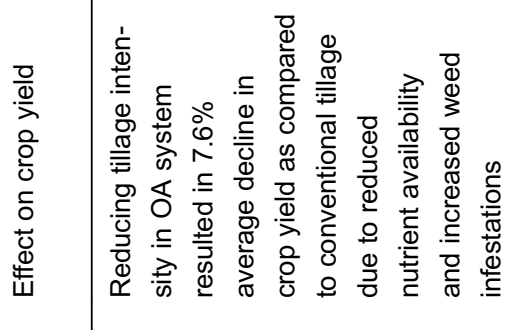

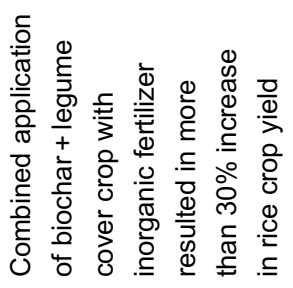

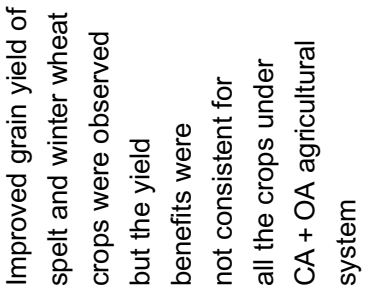

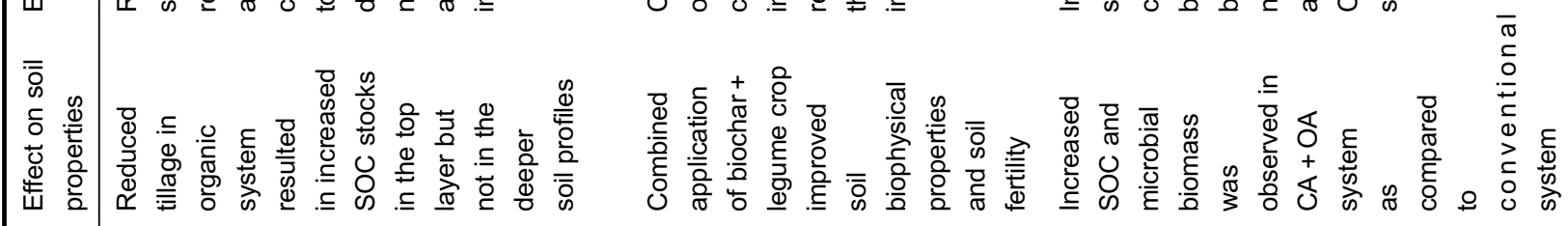

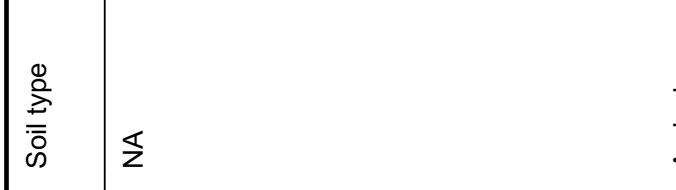

$\frac{\overline{0}}{0.0}$

$\frac{0}{\overline{0}}$

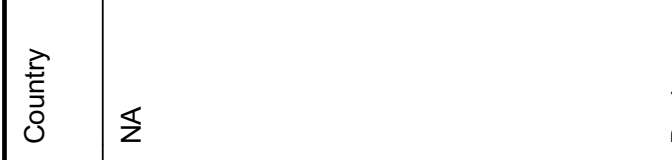

$\begin{array}{ll}\stackrel{5}{\bar{D}} & \frac{5}{\overline{0}} \\ \infty & \text { के }\end{array}$

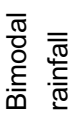

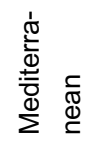

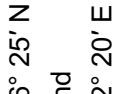

禜

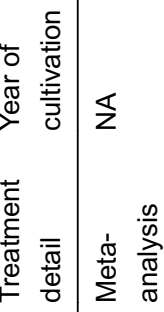

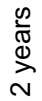

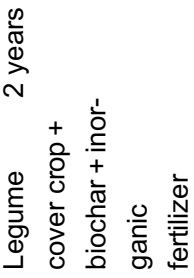

$\frac{\sqrt{0}}{\overline{0}}$

๕ 음

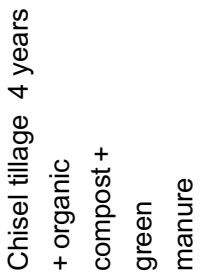

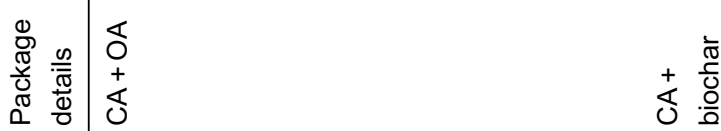

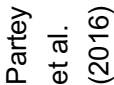

ơ
+
S

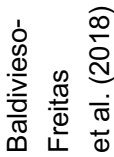




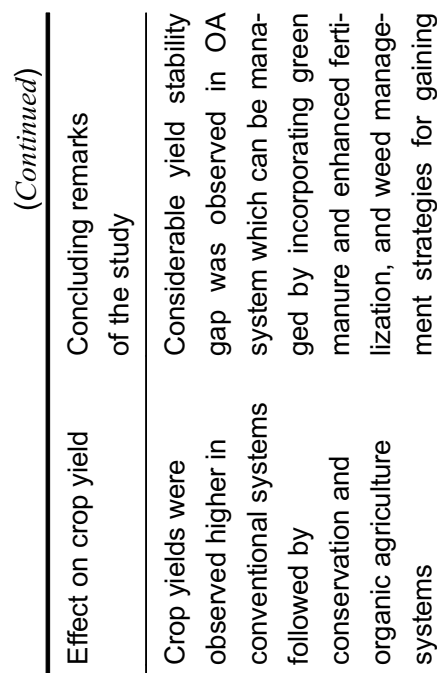

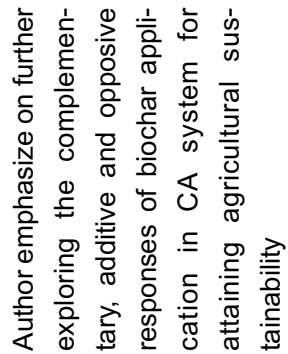

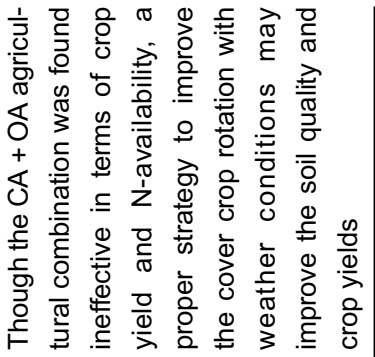

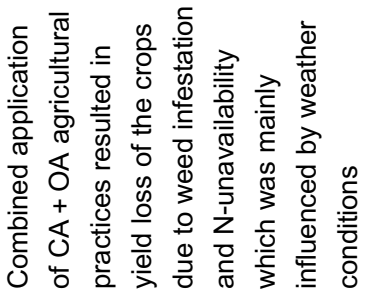

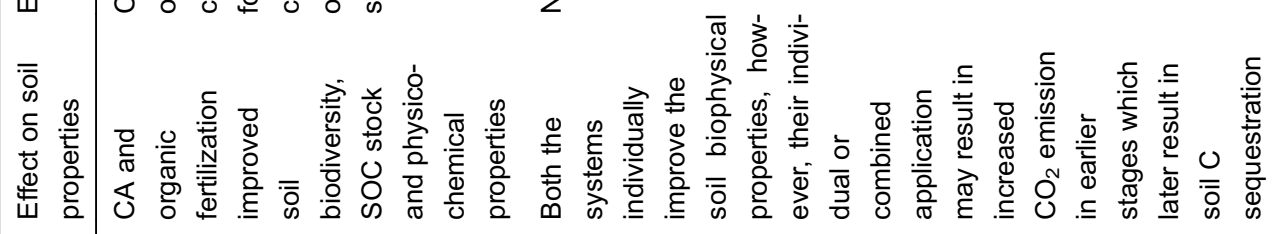

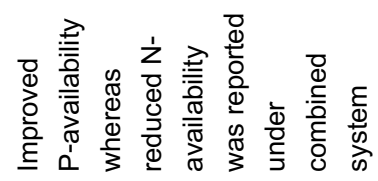

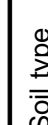

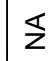

$\overleftarrow{z}$

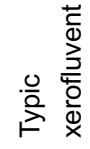

응

$\S$

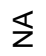

좊

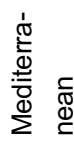

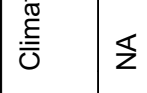

$\S$

วัฒ 함

飞

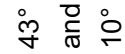

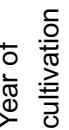

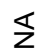

$\overleftarrow{z}$

$\stackrel{\infty}{\stackrel{\infty}{\varpi}}$

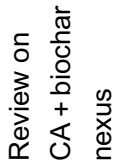

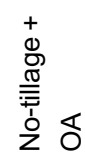

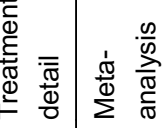

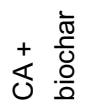

S
+
$\mathbb{0}$

产

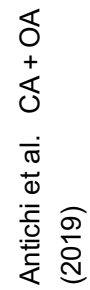

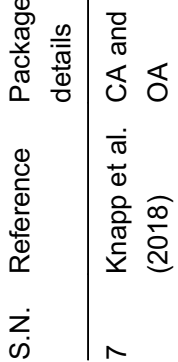



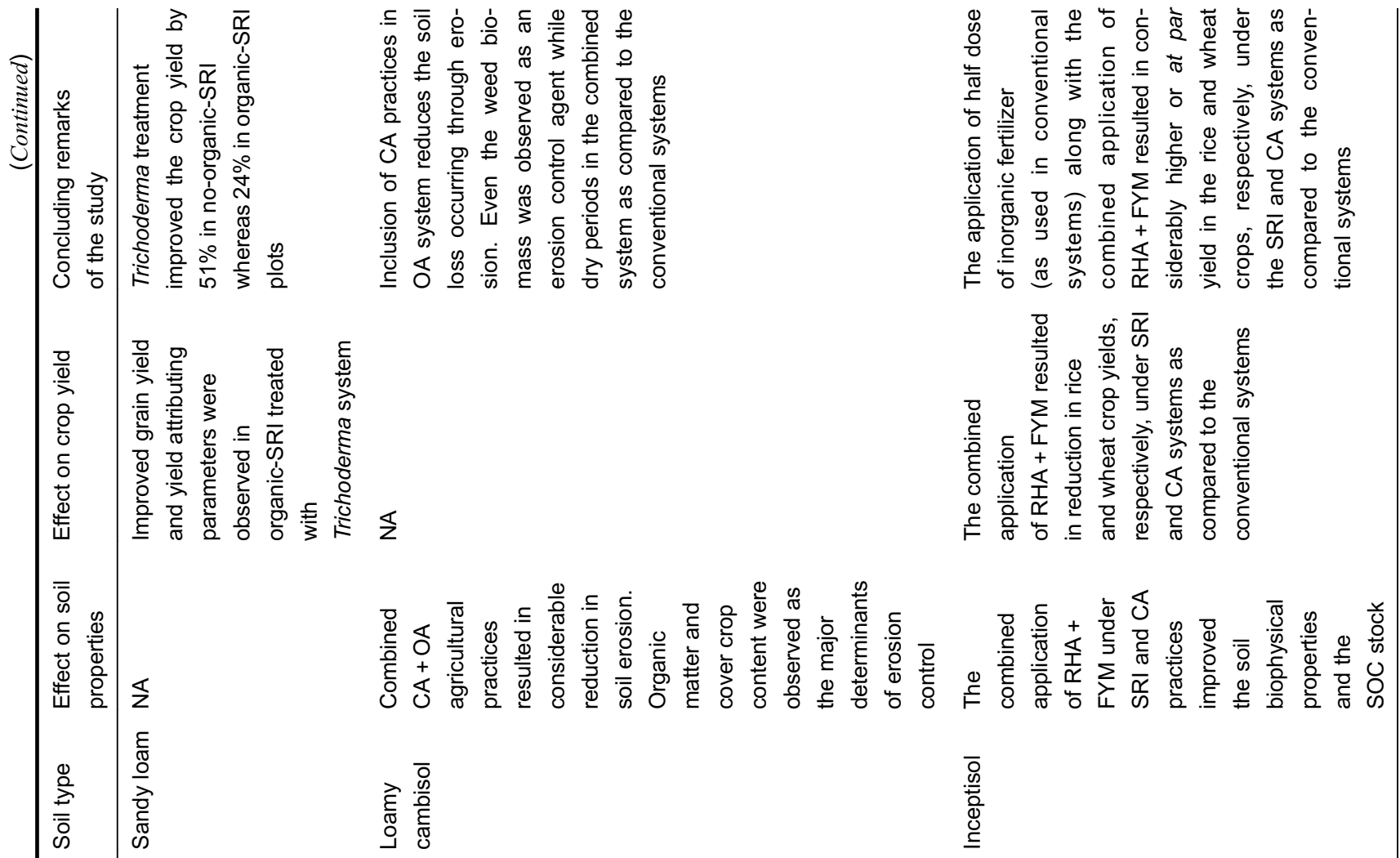

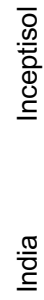

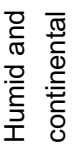

ż

ㅎํㅇ

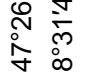

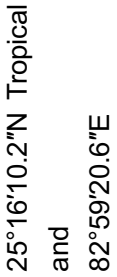

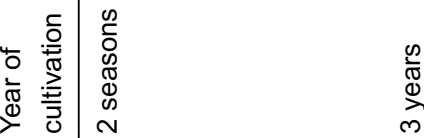

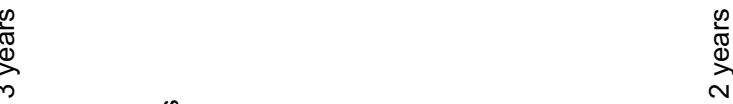

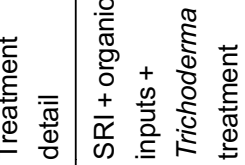
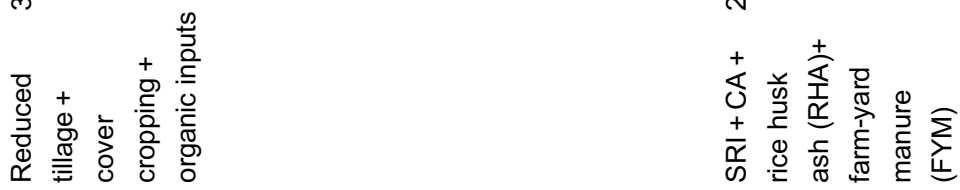

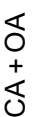
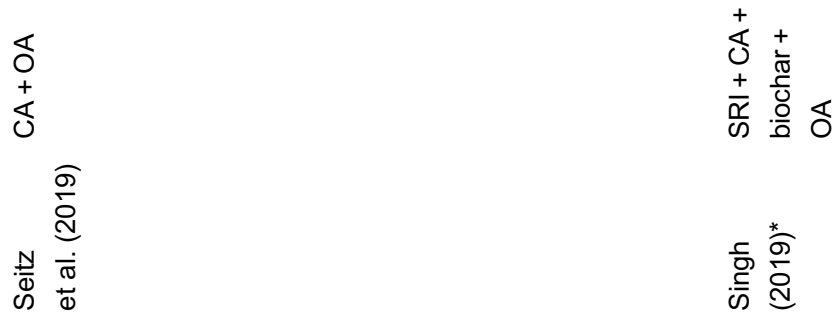

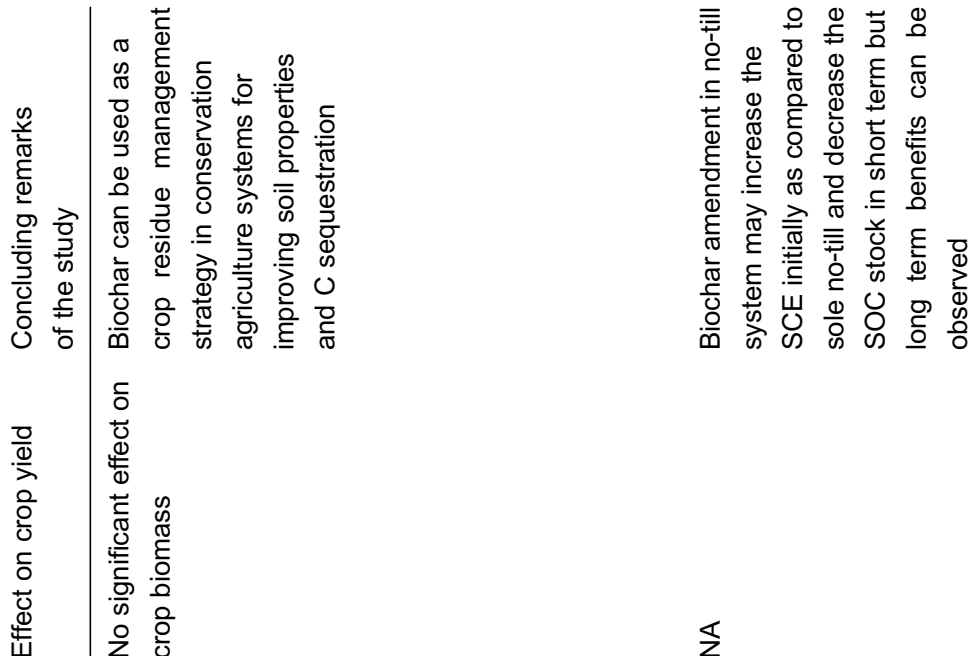

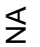

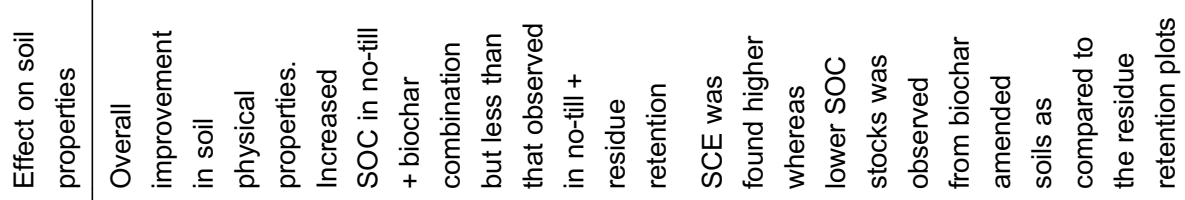

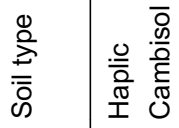

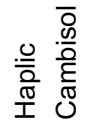

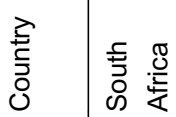

吾

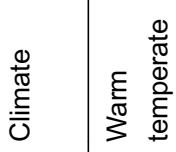

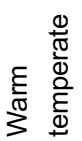

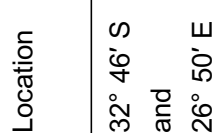

ڤ

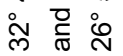

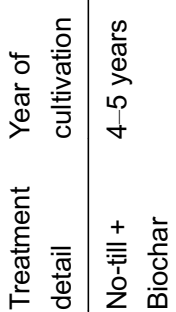

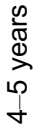

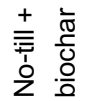

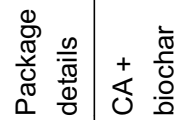

\&

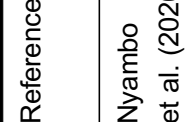

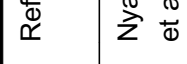

$\sum_{i \infty}^{\infty}$

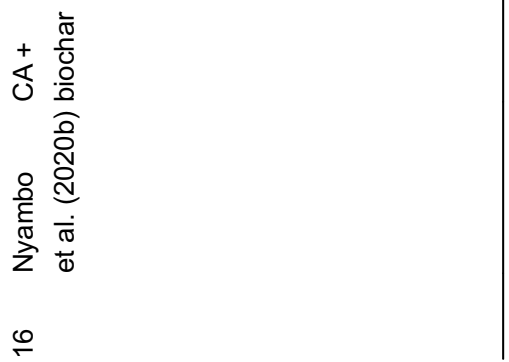




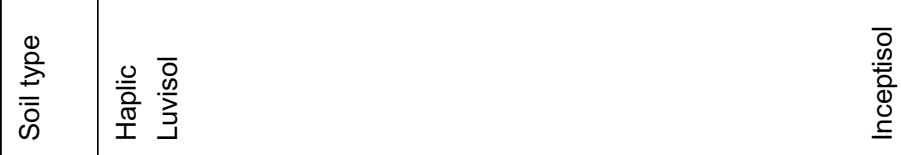

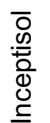

辛

$\stackrel{\frac{0 \pi}{0}}{\underline{\underline{0}}}$

$\frac{\overline{0}}{\frac{0}{2}}$

崩

กับ

ڤั.

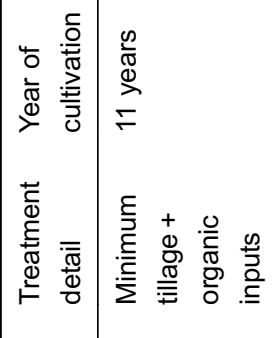

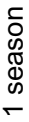

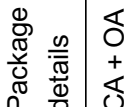

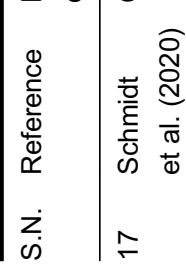

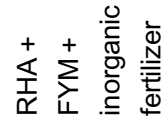

$\frac{+}{\frac{+}{0}}$

बं

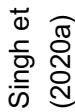




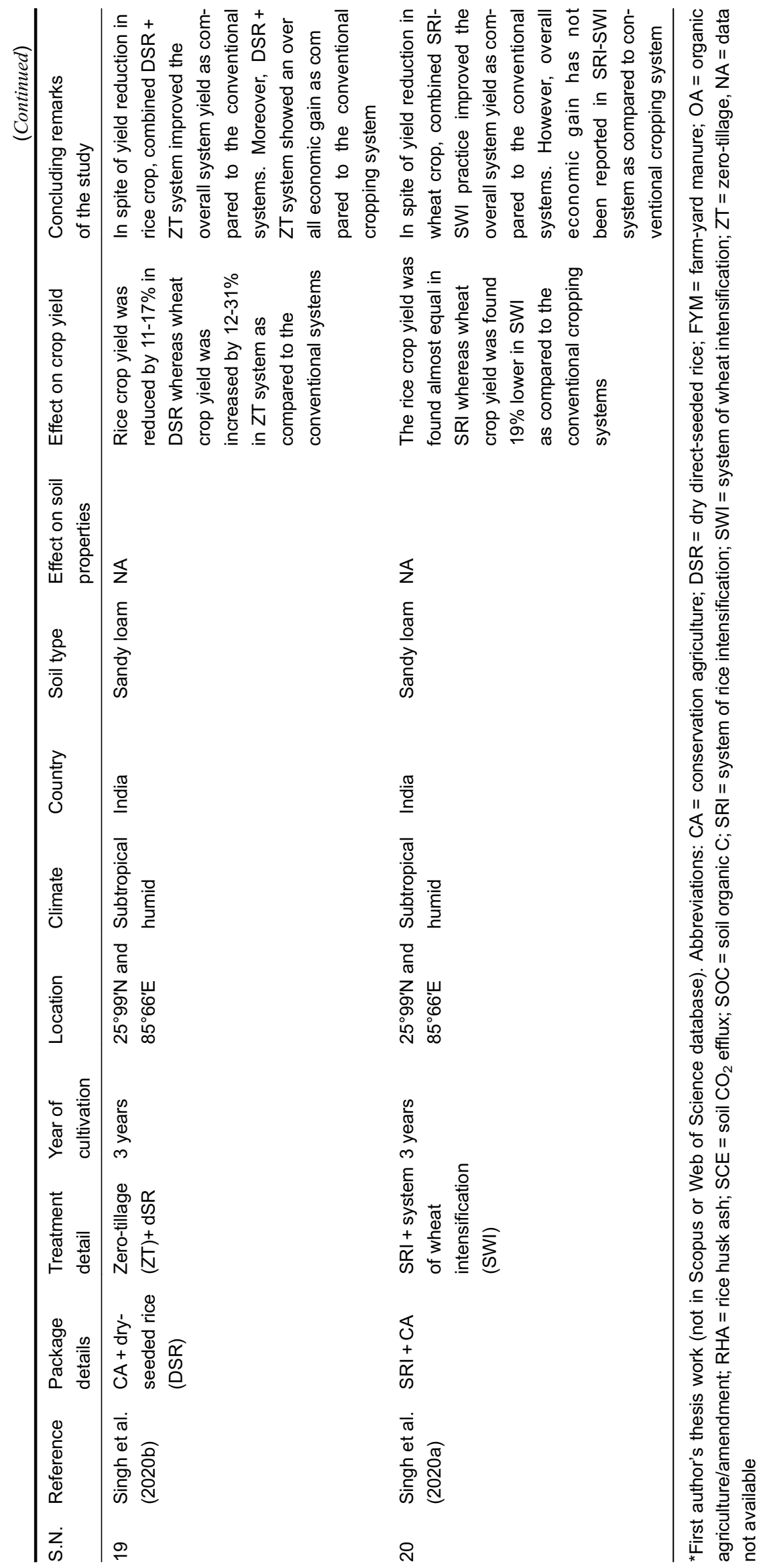


initially (Kassam et al., 2011; Kassam and Brammer, 2016).

(iii) Weed infestations under combined conservationorganic agriculture systems due to tillage reductions is another major challenge (Knapp and van der Heijden, 2018; Antichi et al., 2019; Vincent-Caboud et al., 2019).

(iv) Nutrient immobilization by the microbes can be observed under high $\mathrm{C} / \mathrm{N}$ ratio biochar, organic manure and crop residue application (Baldivieso-Freitas et al., 2018; Peter, 2018; Antichi et al., 2019; Singh et al., 2019b).

(v) Since most of the emergent agronomic practices are based on organic-inputs for improving inherent soil health, the increased labile nutrient availability may enhance the microbial activities resulting in higher soil $\mathrm{CO}_{2}$ efflux and other $\mathrm{GHG}$ emissions in the short term (Singh et al., 2019b; Nyambo et al., 2020b). However, these adaptations will lead to build-up of considerable SOC stock and reduced disturbances from the tillage may increase the fungal diversity and mycelia growth which leads to substantial soil $\mathrm{C}$ sequestration in longterm (Singh, 2019).

(vi) Nutrient leaching to the local environment may also be observed in case of unpredicted rainfall events as the case of global climatic variability. However, this may be an occasional phenomenon which can be managed by proper management activities and precision agriculture practices.

(vii) Socio-economic status of farmers and government policies are also the major challenge for wider adoption of compatible agricultural packages under different agro-climatic zones. Some of the practices (e.g., the SRI and organic farming) have more suitability for small landholding farmers whereas other (e.g., conservation agriculture and biochar amendment) has more ligation for large landholding farmers which may limit the regular distribution of the adoption of the compatible agronomic packages at wider scale.

The limitations are site- and climate-specific in nature. The studies from Mediterranean climate reported more nutrient unavailability under combined agronomic practices due to their long cold conditions which resulted in either nutrient immobilization or reduced mineralization (Campiglia et al., 2015; Baldivieso-Freitas et al., 2018; Antichi et al., 2019). On the contrary, higher mineralization, and thus, faster decomposition of organic content has been observed in tropical and warm temperate conditions (Partey et al., 2016; Khadka and Uphoff, 2019; Singh et al., 2019b; Nyambo et al., 2020a, 2020b). These limitations can be managed by improving crop rotation policies related to different climatic conditions, mechanical weed management, incorporation of moderate/ minimal dose of inorganic fertilizers at critical growth stages of crops and providing incentives to the farmers in case of yield penalty (Cooper et al., 2016; Baldivieso-Freitas et al., 2018; Antichi et al., 2019; Singh et al., 2019b; Vincent-Caboud et al., 2019). Moreover, there is a need to strike the balance between the socio-economic balance and incentives in the form of reward and subsidies to farmers having limited resources for wider adoption of a particular package. Since the agriculture and related stakeholders are the backbones of several developing countries, it is an urgent need to think and act on prioritizing the compatible agronomic-package based agriculture for attaining true sustainability in agriculture.

\section{Conclusions and research outlook}

In this study, we identified that the research on the resourceconservative emergent agronomic practices has been increasing nowadays. However, the research on emergent agronomic practices is mostly done in isolated way for a particular agronomic practice. Under current changing climate scenario, in spite of looking for individual practice, a holistic understanding of the system by considering a package of practices may help in developing broader view on the environmental impacts of those practices. The review identified some studies focusing on the combined application of a few agronomic practices for better resource utilization and management. The bibliometric approach helped in identification of such research trends. The trend analysis revealed that we may witness a number of studies dealing with the compatible agronomic packages in the coming years. The researches, though a few only, on compatible agronomic packages reported some interesting results which may help in buffering the nutrient cycling under climatic variability. Therefore, there is an urgent need to focus on various soil-plantwater relationships, in general, and soil-cropping systemgreenhouse gas emissions, in particular, by developing compatible packages of agricultural practices for different agro-climatic zones, globally.

\section{Acknowledgments}

Authors acknowledge the financial support as research fellowship from the University Grants Commission (UGC), New Delhi, India. Authors extend their thanks to handling editor and anonymous reviewers for their thoughtful suggestions and critical comments for improving this article.

\section{Authors' contribution}

ASR conceived the idea which was further elaborated by RS. RS, PV and TK did extensive literature survey, outlined the manuscript structure and prepared the figures of the manuscript. RS and PV drafted the original manuscript which was thoroughly reviewed by BPS and ASR. RS and ASR finalized the manuscript.

\section{Compliance with the ethical standards}

Authors declare that they do not have any conflict of interest among them. The manuscript is drafted by following all the guidelines of the ethical standards.

\section{References}

Abdalla, K., Chivenge, P., Ciais, P., Chaplot, V., 2016. No-tillage 
lessens soil $\mathrm{CO}_{2}$ emissions the most under arid and sandy soil conditions: results from a meta-analysis. Biogeosciences 13, 3619-3633.

Abdalla, M., Osborne, B., Lanigan, G., Forristal, D., Williams, M., Smith, P., Jones, M.B., 2013. Conservation tillage systems: a review of its consequences for greenhouse gas emissions. Soil Use and Management 29, 199-209.

Agbna, G.H., Dongli, S., Zhipeng, L., Elshaikh, N.A., Guangcheng, S., Timm, L.C., 2017. Effects of deficit irrigation and biochar addition on the growth, yield, and quality of tomato. Scientia Horticulturae 222, 90-101.

Alluvione, F., Halvorson, A.D., Del Grosso, S.J., 2009. Nitrogen, tillage, and crop rotation effects on carbon dioxide and methane fluxes from irrigated cropping systems. Journal of Environmental Quality 38, 2023-2033.

Alroe, H.F., Læssøe, J., Moller, H., Noe, E., 2016. Opportunities and challenges for multicriteria assessment of food system sustainability. Ecology and Society 21, 38.

Antichi, D., Sbrana, M., Martelloni, L., Abou Chehade, L., Fontanelli, M., Raffaelli, M., Mazzoncini, M., Peruzzi, A., Frasconi, C., 2019. Agronomic performances of organic field vegetables managed with conservation agriculture techniques: A study from Central Italy. Agronomy (Basel) 9, 810.

Aria, M., Cuccurullo, C., 2017. Bibliometrix: An R-tool for comprehensive science mapping analysis. Journal of Informetrics 11, 959 975.

Baldivieso-Freitas, P., Blanco-Moreno, J.M., Armengot, L., Chamorro, L., Romanyà, J., Sans, F.X., 2018. Crop yield, weed infestation and soil fertility responses to contrasted ploughing intensity and manure additions in a Mediterranean organic crop rotation. Soil \& Tillage Research 180, 10-20.

Barea, J.M., 2015. Future challenges and perspectives for applying microbial biotechnology in sustainable agriculture based on a better understanding of plant-microbiome interactions. Journal of Soil Science and Plant Nutrition 15, 261-282.

Bhuiyan, S.I., Tuong, T.P., 1995. Water Use in Rice Production: Issues, Research Opportunities and Policy Implications. Proceedings of the Inter-Center Water Management Workshop. International Irrigation Management Institute, Colombo, and World Health Organization, Colombo.

Biederman, L.A., Harpole, W.S., 2013. Biochar and its effects on plant productivity and nutrient cycling: a meta-analysis. Global Change Biology. Bioenergy 5, 202-214.

Bose, B., Mondal, S., 2013. Climate change and sustainable agriculture in context to seed priming and role of nitrate. Vegetos 26, 192-204.

Burney, J.A., Davis, S.J., Lobell, D.B., 2010. Greenhouse gas mitigation by agricultural intensification. Proceedings of the National Academy of Sciences of the United States of America 107, 12052-12057.

Campiglia, E., Mancinelli, R., De Stefanis, E., Pucciarmati, S., Radicetti, E., 2015. The long-term effects of conventional and organic cropping systems, tillage managements and weather conditions on yield and grain quality of durum wheat (Triticum durum Desf.) in the Mediterranean environment of Central Italy. Field Crops Research 176, 34-44.
Ceja-Navarro, J.A., Rivera-Orduna, F.N., Patiño-Zúñiga, L., VilaSanjurjo, A., Crossa, J., Govaerts, B., Dendooven, L., 2010. Phylogenetic and multivariate analyses to determine the effects of different tillage and residue management practices on soil bacterial communities. Applied and Environmental Microbiology 76, 3685-3691.

Chappell, M.J., LaValle, L.A., 2011. Food security and biodiversity: can we have both? An agroecological analysis. Agriculture and Human Values 28, 3-26.

Choi, J.D., Park, W.J., Park, K.W., Lim, K.J., 2013. Feasibility of SRI methods for reduction of irrigation and NPS pollution in Korea. Paddy and Water Environment 11, 241-248.

Cobo, M.J., López-Herrera, A.G., Herrera-Viedma, E., Herrera, F., 2011. An approach for detecting, quantifying, and visualizing the evolution of a research field: A practical application to the fuzzy sets theory field. Journal of Informetrics 5, 146-166.

Cooper, J., Baranski, M., Stewart, G., Nobel-de Lange, M., Bàrberi, P., Fließbach, A., Peigné, J., Berner, A., Brock, C., Casagrande, M., Crowley, O., David, C., De Vliegher, A., Döring, T.F., Dupont, A., Entz, M., Grosse, M., Haase, T., Halde, C., Hammerl, V., Huiting, H., Leithold, G., Messmer, M., Schloter, M., Sukkel, W., van der Heijden, M.G.A., Willekens, K., Wittwer, R., Mäder, P., 2016. Shallow non-inversion tillage in organic farming maintains crop yields and increases soil $\mathrm{C}$ stocks: a meta-analysis. Agronomy for Sustainable Development 36, 22.

Cornell International Institute for Food, Agriculture and Development, CIIFAD, 2014. SRI methodology. Available via http://sri.ciifad. cornell.edu/aboutsri/methods/index.html. Accessed on 3 April 2014.

Das, A., Layek, J., Ramkrushna, G.I., Patel, D.P., Choudhury, B.U., Krishnappa, R., Buragohain, J., Yadav, G.S., 2018. Modified system of rice intensification for higher crop and water productivity in Meghalaya, India: opportunities for improving livelihoods for resource-poor farmers. Paddy and Water Environment 16, 23-34.

Das, T.K., Bandyopadhyay, K.K., Bhattacharyya, R., Sudhishri, S., Sharma, A.R., Behera, U.K., Saharawat, Y.S., Sahoo, P.K., Pathak, H., Vyas, A.K., Bhar, L.M., Gupta, H.S., Gupta, R.K., Jat, M.L., 2016. Effects of conservation agriculture on crop productivity and water-use efficiency under an irrigated pigeonpea-wheat cropping system in the western Indo-Gangetic Plains. Journal of Agricultural Science 154, 1327-1342.

Dass, A., Kaur, R., Choudhary, A.K., Pooniya, V., Raj, R., Rana, K.S., 2015. System of rice (Oryza sativa) intensification for higher productivity and resource use efficiency — A review. Indian Journal of Agronomy 60, 1-19.

Deelstra, J., Nagothu, U.S., Kakumanu, K.R., Kaluvai, Y.R., Kallam, S. R., 2018. Enhancing water productivity using alternative rice growing practices: a case study from Southern India. Journal of Agricultural Science 156, 673-679.

Delgado, J.A., Groffman, P.M., Nearing, M.A., Goddard, T., Reicosky, D., Lal, R., Kitchen, N.R., Rice, C.W., Towery, D., Salon, P., 2011. Conservation practices to mitigate and adapt to climate change. Journal of Soil and Water Conservation 66, 118A-129A.

DeLuca, T.H., Gundale, M.J., MacKenzie, M.D., Jones, D.L., 2015. Biochar effects on soil nutrient transformations. Biochar for Environmental Management: Science. Technology and Implemen- 
tation 2, 421-454.

Dhillon, B.S., Kataria, P., Dhillon, P.K., 2010. National food security vis-à-vis sustainability of agriculture in high crop productivity regions. Current Science 98, 33-36.

Doran, J.W., Parkin, T.B., 1994. Defining and Assessing Soil Quality. In: Doran, J.W., Coleman, D.C., Bezdicek, D.F., Stewart, B.A., eds. Defining Soil Quality for a Sustainable Environment, (definingsoilqua), pp.1-21.

Du, T., Kang, S., Zhang, J., Davies, W.J., 2015. Deficit irrigation and sustainable water-resource strategies in agriculture for China's food security. Journal of Experimental Botany 66, 2253-2269.

Ehrlich, P.R., Harte, J., 2015. Food security requires a new revolution. International Journal of Environmental Studies 72, 908-920.

Faloye, O.T., Alatise, M.O., Ajayi, A.E., Ewulo, B.S., 2019. Effects of biochar and inorganic fertiliser applications on growth, yield and water use efficiency of maize under deficit irrigation. Agricultural Water Management 217, 165-178.

Fischer, D., Glaser, B., (2012) Synergisms between Compost and Biochar for Sustain Able Soil Amelioration. In: Kumar, S., Bharti, A. eds. Management of Organic Waste. Rijeka, InTech, pp. 167-198.

Foley, J.A., Ramankutty, N., Brauman, K.A., Cassidy, E.S., Gerber, J. S., Johnston, M., Mueller, N.D., O'Connell, C., Ray, D.K., West, P. C., Balzer, C., Bennett, E.M., Carpenter, S.R., Hill, J., Monfreda, C., Polasky, S., Rockström, J., Sheehan, J., Siebert, S., Tilman, D., Zaks, D.P.M., 2011. Solutions for a cultivated planet. Nature 478 , 337-342.

Food and Agriculture Organization, FAO (2008) An international technical workshop Investing in sustainable crop intensification The case for improving soil health. Integrated Crop Management Vol. 6-2008. FAO Rome: 22-24 July 2008.

Food and Agriculture Organization, FAO (2011) WFP,"The State of Food Insecurity in the World: How does international price volatility affect domestic economies and food security?". Food and Agriculture Organization of the United Nations, 99.

Food and Agriculture Organization, FAO 2015. Status of the world's soil resources (SWSR)-main report. Food and agriculture organization of the United Nations and intergovernmental technical panel on soils, Rome, Italy, 650.

Garbach, K., Milder, J.C., DeClerck, F.A., Montenegro de Wit, M., Driscoll, L., Gemmill-Herren, B., 2017. Examining multi-functionality for crop yield and ecosystem services in five systems of agroecological intensification. International Journal of Agricultura Sustainability $15,11-28$.

Gathala, M.K., Ladha, J.K., Saharawat, Y.S., Kumar, V., Kumar, V., Sharma, P.K., 2011. Effect of tillage and crop establishment methods on physical properties of a medium-textured soil under a seven-year rice - wheat rotation. Soil Science Society of America Journal 75 , 1851-1862

Gill, S.S., Tuteja, N., 2010. Reactive oxygen species and antioxidant machinery in abiotic stress tolerance in crop plants. Plant Physiology and Biochemistry 48, 909-930.

Godfray, H.C.J., Garnett, T., 2014. Food security and sustainable intensification. Philosophical Transactions of the Royal Society of London. Series B, Biological Sciences 369, 20120273.

Gourley, C.J.P., Allan, D.L., Russelle, M.P., 1994. Plant nutrient efficiency: A comparison of definitions and suggested improve- ment. Plant and Soil 158, 29-37.

Granatstein, D., Kruger, C., Collins, H., Garcia-Perez, M., Yoder, J., 2009. Use of biochar from the pyrolysis of waste organic material as a soil amendment. Center for Sustaining Agric. Nat. Res. Washington State University, Wenatchee, WA. WSDA Interagency Agreement. C, 800248.

Guo, L., Zheng, S., Cao, C., Li, C., 2016. Tillage practices and strawreturning methods affect topsoil bacterial community and organic $\mathrm{C}$ under a rice-wheat cropping system in central China. Scientific Reports 6, 33155.

Guo, L.J., Zhang, Z.S., Wang, D.D., Li, C.F., Cao, C.G., 2015. Effects of short-term conservation management practices on soil organic carbon fractions and microbial community composition under a rice-wheat rotation system. Biology and Fertility of Soils 51, 65-75.

Hadi, A., Inubushi, K., Yagi, K., 2010. Effect of water management on greenhouse gas emissions and microbial properties of paddy soils in Japan and Indonesia. Paddy and Water Environment 8, 319 324.

Inter-Governmental Panel on Climate Change, IPCC, 2007. Climate Change 2007-the PHYSICAL SCIENCE BAsis.

Intergovernmental Panel on Climate Change, IPCC, 2015. Climate Change 2014: Agriculturre Forestry and Other Land Use (AFOLU). Chapter 11. Available at: www.ipcc.ch.

IWMI, 2007. Rice: Feeding the Billions, Chapter 14. In: Molden, D., ed. Water for Food, Water for Life: a Comprehensive Assessment of Water Management in Agriculture. Earthscan/International Water Management Institute, London/Colombo.

Jat, H.S., Kumar, P., Sutaliya, J.M., Kumar, S., Choudhary, M., Singh, Y., Jat, M.L., 2019. Conservation agriculture based sustainable intensification of basmati rice-wheat system in North-West India. Archives of Agronomy and Soil Science 65, 1370-1386.

Jat, R.K., Sapkota, T.B., Singh, R.G., Jat, M.L., Kumar, M., Gupta, R. K., 2014. Seven years of conservation agriculture in a rice-wheat rotation of Eastern Gangetic Plains of South Asia: yield trends and economic profitability. Field Crops Research 164, 199-210.

Kameyama, K., Miyamoto, T., Iwata, Y., Shiono, T., 2016. Influences of feedstock and pyrolysis temperature on the nitrate adsorption of biochar. Soil Science and Plant Nutrition 62, 180-184.

Kassam, A., Brammer, H., 2013. Combining sustainable agricultural production with economic and environmental benefits. Geographical Journal 179, 11-18.

Kassam, A., Brammer, H., 2016. Environmental implications of three modern agricultural practices: Conservation agriculture, the system of rice intensification and precision agriculture. International Journal of Environmental Studies 73, 702-718.

Kassam, A., Friedrich, T., Derpsch, R., Kienzle, J., 2015. Overview of the worldwide spread of conservation agriculture. Field Actions Science Reports 8.

Kassam, A., Friedrich, T., Shaxson, F., Pretty, J., 2009. The spread of conservation agriculture: justification, sustainability and uptake. International Journal of Agricultural Sustainability 7, 292-320.

Kassam, A., Stoop, W., Uphoff, N., 2011. Review of SRI modifications in rice crop and water management and research issues for making further improvements in agricultural and water productivity. Paddy and Water Environment 9, 163-180.

Khadka, R.B., Uphoff, N., 2019. Effects of Trichoderma seedling 
treatment with System of Rice Intensification management and with conventional management of transplanted rice. PeerJ 7, e5877.

Khorami, S., Kazemeini, S., Afzalinia, S., Gathala, M., 2018. Changes in soil properties and productivity under different tillage practices and wheat genotypes: a short-term study in Iran. Sustainability 10, 3273.

Kirkegaard, J.A., Hunt, J.R., McBeath, T.M., Lilley, J.M., Moore, A., Verburg, K., Robertson, M., Oliver, Y., Ward, P.R., Milroy, S., Whitbread, A.M., 2014. Improving water productivity in the Australian Grains industry - a nationally coordinated approach. Crop \& Pasture Science 65, 583-601.

Knapp, S., van der Heijden, M.G., 2018. A global meta-analysis of yield stability in organic and conservation agriculture. Nature Communications 9, 3632.

Knowler, D., Bradshaw, B., 2007. Farmers' adoption of conservation agriculture: A review and synthesis of recent research. Food Policy $32,25-48$.

Kumar, A., Verma, J.P., 2018. Does plant - microbe interaction confer stress tolerance in plants: a review? Microbiological Research 207, 41-52.

Kumar, M., Singh, D.P., Prabha, R., Sharma, A.K., 2015. Role of Cyanobacteria in Nutrient Cycle and Use Efficiency in the Soil. In: Rakshit, A., Avijit, H.B., Sen, S., eds. Nutrient Use Efficiency: from Basics to Advances. Springer, New Delhi. pp. 163-171.

Kumar, V., Gathala, M.K., Saharawat, Y.S., Parihar, C.M., Kumar, R., Kumar, R., Jat, M.L., Jat, A.S., Mahala, D.M., Kumar, L., Nayak, H. S., Parihar, M.D., Rai, V., Jewlia, H., Kuri, B.R., 2019. Impact of tillage and crop establishment methods on crop yields, profitability and soil physical properties in rice-wheat system of Indo-Gangetic Plains of India. Soil Use and Management 35, 303-313

Kumara, O., Sannathimmappa, H.G., Danaraddi, V.S., Basavarajappa, D.N., Pasha, A., 2016. Resource conservation technology in different paddy ecosystems. Research on Crops 17, 407-414.

Kumari, M., Chakraborty, D., Gathala, M.K., Pathak, H., Dwivedi, B.S., Tomar, R.K., Garg, R.N., Singh, R., Ladha, J.K., 2011. Soil aggregation and associated organic carbon fractions as affected by tillage in a rice-wheat rotation in North India. Soil Science Society of America Journal 75, 560-567.

Lal, R., 2004. Soil carbon sequestration impacts on global climate change and food security. Science 304, 1623-1627.

Lal, R., 2008. Crop residues as soil amendments and feedstock for bioethanol production. Waste Management (New York, N.Y.) 28, 747-758.

Lal, R., 2013. Intensive agriculture and the soil carbon pool. Journal of Crop Improvement 27, 735-751.

Lal, R., 2015. Restoring soil quality to mitigate soil degradation. Sustainability 7, 5875-5895.

Lal, R., 2020. Managing soils for negative feedback to climate change and positive impact on food and nutritional security. Soil Science and Plant Nutrition 66, 1-9.

Li, C., Xiong, Y., Qu, Z., Xu, X., Huang, Q., Huang, G., 2018. Impact of biochar addition on soil properties and water-fertilizer productivity of tomato in semi-arid region of Inner Mongolia, China. Geoderma 331, 100-108.

Lienhard, P., Tivet, F., Chabanne, A., Dequiedt, S., Lelièvre, M.,
Sayphoummie, S., Leudphanane, B., Prévost-Bouré, N.C., Séguy, L., Maron, P.A., Ranjard, L., 2013. No-till and cover crops shift soil microbial abundance and diversity in Laos tropical grasslands. Agronomy for Sustainable Development 33, 375-384.

Lorenz, K., Lal, R., Ehlers, K., 2019. Soil organic carbon stock as an indicator for monitoring land and soil degradation in relation to United Nations' Sustainable Development Goals. Land Degradation \& Development 30, 824-838.

Millennium Ecosystem Assessment Board, 2005. Ecosystems and Human Well-Being Scenarios. Island Press, Washington DC.

Mishra, A., Kumar, P., Noble, A., 2013. Assessing the potential of SRI management principles and the FFS approach in Northeast Thailand for sustainable rice intensification in the context of climate change. International Journal of Agricultural Sustainability 11, 4-22.

Mishra, A., Whitten, M., Ketelaar, J.W., Salokhe, V.M., 2006. The system of rice intensification (SRI): a challenge for science, and an opportunity for farmer empowerment towards sustainable agriculture. International Journal of Agricultural Sustainability 4, 193-212.

Nyambo, P., Chiduza, C., Araya, T., 2020a. Effect of conservation agriculture on selected soil physical properties on a haplic cambisol in Alice, Eastern Cape, South Africa. Archives of Agronomy and Soil Science 11, 1-4

Nyambo, P., Cornelius, C., Araya, T., 2020b. Carbon dioxide fluxes and carbon stocks under conservation agricultural practices in South Africa. Agriculture 10, 374.

Oorts, K., Merckx, R., Gréhan, E., Labreuche, J., Nicolardot, B., 2007. Determinants of annual fluxes of $\mathrm{CO}_{2}$ and $\mathrm{N}_{2} \mathrm{O}$ in long-term notillage and conventional tillage systems in northern France. Soil \& Tillage Research 95, 133-148.

Parihar, M.D., Parihar, C.M., Nanwal, R.K., Singh, A.K., Jat, S.L., Nayak, H.S., Ghasal, P.C., Jewlia, H.R., Choudhary, M., Jat, M.L., 2019. Effect of different tillage and residue management practices on crop and water productivity and economics in maize (Zea mays) based rotations. Indian Journal of Agricultural Sciences 89, 360 366.

Partey, S.T., Saito, K., Preziosi, R.F., Robson, G.D., 2016. Biochar use in a legume-rice rotation system: effects on soil fertility and crop performance. Archives of Agronomy and Soil Science 62, 199215.

Pascual, V., Wang, Y.M., 2017. Impact of water management on rice varieties, yield, and water productivity under the system of rice intensification in Southern Taiwan. Water (Basel) 9, 3.

Perfecto, I., Vandermeer, J., 2010. The agroecological matrix as alternative to the land-sparing/agriculture intensification model. Proceedings of the National Academy of Sciences of the United States of America 107, 5786-5791.

Peter, P.C., 2018. Biochar and conservation agriculture nexus: Synergy and research gaps for enhanced sustainable productivity in degraded soils. Communications in Soil Science and Plant Analysis 49, 389-403.

Pretty, J.N., 1995. Regenerating Agriculture: Policies and Practice for Sustainability and Self-reliance. Joseph Henry Press.

Qu, J., Li, B., Wei, T., Li, C., Liu, B., 2014. Effects of rice-husk ash on soil consistency and compactibility. Catena 122, 54-60.

Raj, R., Kumar, A., Solanki, I.S., Dhar, S., Dass, A., Gupta, A.K., 
Pandey, U.C., 2017. Influence of crop establishment methods on yield, economics and water productivity of rice cultivars under upland and lowland production ecologies of Eastern Indo-Gangetic Plains. Paddy and Water Environment 15, 861-877.

Reeves, S.H., Somasundaram, J., Wang, W.J., Heenan, M.A., Finn, D., Dalal, R.C., 2019. Effect of soil aggregate size and long-term contrasting tillage, stubble and nitrogen management regimes on $\mathrm{CO}_{2}$ fluxes from a Vertisol. Geoderma 337, 1086-1096.

Rupela, O.P., Wani, S.P., Kranthi, M., Humayun, P., Satyanarayana, A., Goud, V., Reddy, P.L., 2006. Comparing soil properties of farmers' fields growing rice by SRI and conventional methods. In: Proceedings of 1st National SRI Symposium. pp. 17-18.

Saikia, S.P., Bora, D., Goswami, A., Mudoi, K.D., Gogoi, A., 2012. A review on the role of Azospirillum in the yield improvement of nonleguminous crops. African Journal of Microbiological Research 6, 1085-1102.

Sapkota, T.B., Mazzoncini, M., Bàrberi, P., Antichi, D., Silvestri, N., 2012. Fifteen years of no till increase soil organic matter, microbial biomass and arthropod diversity in cover crop-based arable cropping systems. Agronomy for Sustainable Development 32, 853-863.

Schmidt, J.H., Hallmann, J., Finckh, M.R., 2020. Bacterivorous nematodes correlate with soil fertility and improved crop production in an organic minimum tillage system. Sustainability 12 , 6730 .

Schulz, H., Glaser, B., 2012. Effects of biochar compared to organic and inorganic fertilizers on soil quality and plant growth in a greenhouse experiment. Journal of Plant Nutrition and Soil Science 175, 410-422.

Seitz, S., Goebes, P., Puerta, V.L., Pereira, E.I., Wittwer, R., Six, J., van der Heijden, M.G., Scholten, T., 2019. Conservation tillage and organic farming reduce soil erosion. Agronomy for Sustainable Development 39, 4.

Sharif, A., 2011. Technical adaptations for mechanized SRI production to achieve water saving and increased profitability in Punjab, Pakistan. Paddy and Water Environment 9, 111-119.

Singh, J., Sidhu, R.S., 2006. Accounting for impact of environmental degradation in agriculture of Indian Punjab. Agricultural Economics Research Review 19, 37-48.

Singh, K.P., Ghoshal, N., Singh, S., 2009. Soil carbon dioxide flux, carbon sequestration and crop productivity in a tropical dryland agroecosystem: influence of organic inputs of varying resource quality. Applied Soil Ecology 42, 243-253.

Singh, M., Kumar, P., Kumar, V., Solanki, I.S., McDonald, A.J., Kumar, A., Poonia, S.P., Kumar, V., Ajay, A., Kumar, A., Singh, D.K., Balwinder-Singh, S., Singh, R.K., Malik, 2020b. Intercomparison of crop establishment methods for improving yield and profitability in the rice-wheat system of Eastern India. Field Crops Research 250, 107776.

Singh, R., 2019. Environmental Impact Analysis of Traditional and Emergent Agronomic Practices in Indo-Gangetic plains of India. Ph.D. Thesis submitted to Banaras Hindu University, Varanasi, India.

Singh, R., Babu, J.N., Kumar, R., Srivastava, P., Singh, P., Raghubanshi, A.S., 2015. Multifaceted application of crop residue biochar as a tool for sustainable agriculture: an ecological perspective. Ecological Engineering 77, 324-347.

Singh, R., Singh, H., Raghubanshi, A.S., 2019a. Challenges and opportunities for agricultural sustainability in changing climate scenarios: a perspective on Indian agriculture. Tropical Ecology 60, 167-185.

Singh, R., Singh, P., Singh, H., Raghubanshi, A.S., 2019c. Impact of sole and combined application of biochar, organic and chemical fertilizers on wheat crop yield and water productivity in a dry tropical agro-ecosystem. Biochar 1, 229-235.

Singh, R., Srivastava, P., Bhadouria, R., Yadav, A., Singh, H., Raghubanshi, A.S., 2020a. Combined application of biochar and farmyard manure reduces wheat crop eco-physiological performance in a tropical dryland agro-ecosystem. Energy, Ecology \& Environment 5, 171-183.

Singh, R., Srivastava, P., Singh, P., Sharma, A.K., Singh, H., Raghubanshi, A.S., 2019b. Impact of rice-husk ash on the soil biophysical and agronomic parameters of wheat crop under a dry tropical ecosystem. Ecological Indicators 105, 505-515.

Singh, Y., Sidhu, H.S., 2014. Management of cereal crop residues for sustainable rice-wheat production system in the Indo-Gangetic plains of India. Proceedings of the Indian National Science Academy 80, 95-114.

Smith, P., Cotrufo, M.F., Rumpel, C., Paustian, K., Kuikman, P.J., Elliott, J.A., McDowell, R., Griffiths, R.I., Asakawa, S., Bustamante, M., House, J.I., Sobocká, J., Harper, R., Pan, G., West, P.C., Gerber, J.S., Clark, J.M., Adhya, T., Scholes, R.J., Scholes, M.C., 2015. Biogeochemical cycles and biodiversity as key drivers of ecosystem services provided by soils. Soil 1, 665-685.

Sparrevik, M., Field, J.L., Martinsen, V., Breedveld, G.D., Cornelissen, G., 2013. Life cycle assessment to evaluate the environmental impact of biochar implementation in conservation agriculture in Zambia. Environmental Science \& Technology 47, 1206-1215.

Srivastava, P., Singh, R., Bhadouria, R., Tripathi, S., Singh, P., Singh, H., Raghubanshi, A.S., 2016b. Organic amendment impact on SOC dynamics in dry tropics: a possible role of relative availability of inorganic-N pools. Agriculture, Ecosystems \& Environment 235, 38-50.

Srivastava, P., Singh, R., Tripathi, S., Raghubanshi, A.S., 2016a. An urgent need for sustainable thinking in agriculture-An Indian scenario. Ecological Indicators 67, 611-622.

Srivastava, P., Singh, R., Tripathi, S., Singh, H., Raghubanshi, A.S., Mishra, P.K., 2018. A new insight into the warming potential of organically amended agro-ecosystems. Organic Agriculture 8, 275-284.

Suryavanshi, P., Singh, Y.V., Prasanna, R., Bhatia, A., Shivay, Y.S., 2013. Pattern of methane emission and water productivity under different methods of rice crop establishment. Paddy and Water Environment 11, 321-329.

Thakur, A.K., Mohanty, R.K., Patil, D.U., Kumar, A., 2014. Impact of water management on yield and water productivity with system of rice intensification (SRI) and conventional transplanting system in rice. Paddy and Water Environment 12, 413-424.

Thakur, A.K., Rath, S., Roychowdhury, S., Uphoff, N., 2010. Comparative performance of rice with system of rice intensification (SRI) and conventional management using different plant spacings. Journal Agronomy \& Crop Science 196, 146-159. 
Thakur, A.K., Uphoff, N.T., 2017. How the system of rice intensification can contribute to climate-smart agriculture. Agronomy Journal 109, 1163-1182.

Thierfelder, C., Chivenge, P., Mupangwa, W., Rosenstock, T.S., Lamanna, C., Eyre, J.X., 2017. How climate-smart is conservation agriculture (CA)?-its potential to deliver on adaptation, mitigation and productivity on smallholder farms in southern Africa. Food Security 9, 537-560.

Uphoff, N., Kassam, A., Harwood, R., 2011. SRI as a methodology for raising crop and water productivity: productive adaptations in rice agronomy and irrigation water management. Paddy and Water Environment 9, 3-11.

Vincent-Caboud, L., Casagrande, M., David, C., Ryan, M.R., Silva, E. M., Peigne, J., 2019. Using mulch from cover crops to facilitate organic no-till soybean and maize production. A review. Agronomy for Sustainable Development 39, 45.

Wang, J., Xiong, Z., Kuzyakov, Y., 2016. Biochar stability in soil: metaanalysis of decomposition and priming effects. Global Change Biology. Bioenergy 8, 512-523.

Wang, Y., Tu, C., Cheng, L., Li, C., Gentry, L.F., Hoyt, G.D., Hu, S., 2011. Long-term impact of farming practices on soil organic carbon and nitrogen pools and microbial biomass and activity. Soil \&
Tillage Research 117, 8-16.

Warnock, D.D., Mummey, D.L., McBride, B., Major, J., Lehmann, J., Rillig, M.C., 2010. Influences of non-herbaceous biochar on arbuscular mycorrhizal fungal abundances in roots and soils: results from growth-chamber and field experiments. Applied Soil Ecology 46, 450 456.

Yadav, D., Rangabhashiyam, S., Verma, P., Singh, P., Devi, P., Kumar, P., Hussain, C.M., Gaurav, G.K., Kumar, K.S., 2021. Environmental and health impacts of contaminants of emerging concerns: recent treatment challenges and approaches. Chemosphere 272, 129492.

Yang, J., Zhang, J., 2010. Crop management techniques to enhance harvest index in rice. Journal of Experimental Botany 61, 31773189.

Zhang, W.J., Lu, M., 2010. Innovational rice-wheat cropping system for higher yield with lower emissions in China, based on the concepts of SRI. Paper from Institute of Crop Science http://sri. ciifad. cornell. edu/countries/china/ChinaSWRI_Zhang2010.pdf.

Zhao, S., Li, K., Zhou, W., Qiu, S., Huang, S., He, P., 2016. Changes in soil microbial community, enzyme activities and organic matter fractions under long-term straw return in north-central China. Agriculture, Ecosystems \& Environment 216, 82-88. 